
UNIVERSITY

OF FLORIDA

LIB R A R IES

SCIENCE ROOM 


\section{THE NATURAL HISTORY OF THE RED-TAILED SKINK, EUMECES EGREGIUS BAIRD}

By

ROBERT HUGHES MOUNT

A DISSERTATION PRESENTED TO THE GRADUATE COUNCIL OF THE UNIVERSITY OF FLORIDA IN PARTIAL FULFILLMENT OF THE REQUIREMENTS FOR THE DEGREE OF DOCTOR OF PHILOSOPHY

UNIVERSITY OF FLORIDA

August, 1961 


\section{ACKNOWLEDGMENTS}

I express my deepest appreciation to Dr. Archie Carr for his direction of this research, for the inspiration and encouragement which he so aptly provided during the course of the study, and for his invaluable aid in composing this dissertation; to Drs. E. C. Bovee, A. M. Laessle, J. N. Layne, Carl Monk, and W. J. Riemer for their suggestions concerning the study and for reading and correcting the manuscript; to Dr. Alan D. Conger for his technical and material assistance in the experimentation on temperature relationships; to Mr. Wilfred Nelll of Silver Springs, Florida, who contributed many specimens and was helpful In many other respects; to Mr. Sam Telford, Jr., who not only supplied much live material, but also took an extremely active interest in the research and provided valuable advice and constructive criticism; to Miss Esther Coogle, who assisted in the preparation of the map and other figures; to Messrs. Robert McFarlane and Timothy Brown for their the and effort in helping to solve my photographic problems; and to Messrs. C. W. Myers, Howard M. Hutchinson, Willlam O. Wirtz, and Andrew Beckenbach, who, among many others, contributed living specimens for use in this study.

I am grateful to the Society of S1gma XI for its financial support of this project and to the National science Poundation for its award of a Sumer Fellowship enabling me to devote the necessary time to the study during a crucial period. 
Finally, I wish to thank the Blology Department, the Florida State Museum, the College of Arts and Sciences, and the Graduate School of the University of Plorida for the splendid cooperation and assistance given me during the perlod of research. 
TABLE OF CONTENTS

Page

A CKNOWLEDGMENTS

LIST OF TABLES

v1

LIST OF FIGURES

v11

INTRODUCT ION

GENERAL METHODS

GEOGRAPHIC RANGE

ECOLOGICAL DISTRIBUTION AND COLLECTING METHODS

TEMPERATURE RELATIONSHIPS

LOCOMOTION

FOOD HABITS

FEEDING BEHAVIOR

ANNUAL CYCLE OF REPRODUCTION AND ACTIVITY . . . . . . . . .

Courtship and Mating

Homosexual behavior . . . . . . . . . . . . . . . . .

Fighting . . . . . . . . . . . . . . . . . .

Preoviposition Period.................

Nests . . . . . . . . . 58

Oviposition and Eggs .................. . . . . 60

Brooding ...................... . . . . . 61

Hatching and the Hatchlings . . . . . . . . . . . . . . . 64

Growth and Development ............... . . . 66

Postnesting Activity ................ 75

PREDATION AND PARASITISM . . . . . . . . . . . . . . . 76

POPULATION DYNAMICS . . . . . . . . . . . . . . 78

Dispersion and structure ............. . . 78

Density and Movements . . . . . . . . . . . . 78 
SUMMARY AND CONCLUSIONS . . . . . . . . . . . . . . . . . 81

LITERATURE CITED . . . . . . . . . . . . . . . . . 84

BIOGRAPHICAL SKETCH . . . . . . . . . . . . . . . . 86 


\section{LIST OF TABLES}

Table

Page

1 Frequency of occurrence of food items in digestive tracts of Eumeces egreglus . . . . . . . . . . 26

2 Prequency of occurrence of food items in digestive tracts of Eumeces egregius by season (Study

Area, Levy County, Florida)

3 Size of female parent, number of eggs per clutch, and dates of oviposition and hatching for 14 clutches of eggs of Eumeces egreglus (1960) . . . . . 59

4 Measurements of freshly laid eggs of Eumeces egreglus in millimeters .............

Size in millimeters of Eumeces egreglus at hatching by geographic locality...............

6 Growth data in millimeters on $\mathrm{s} 1 \mathrm{x}$ groups of $s$ lbling

Bumeces egregius . . . . . . . . . . . . . 


\section{LIST OF FIGURES}

1 Locality records for Eumeces egregius as of June, 1961. . 4

2 Habltats of Eumeces egreglus ............... 9

3 Field and laboratory observations on temperature relationships of Eumeces ezregius ........... 21

4 Breeding coloration in male Eumeces egreglus . . . . . . 34

5 Seasonal variation in size of gonads of male Eumeces egregius (Study Area, Levy County, Florida)..... . 35

6 Mating of Eumeces egregius . . . . . . . . . . . . 40

7 Mating scars on female Euneces egregius . . . . . . . 40

8 Aggressive behavior in male Eumeces egregius . . . . . . 51

9 Seasonal variation in relative freyuency of capture of male and female Eumeces egregius (Study Area, Levy County, Florida) ............. 53

10 Seasonal and sexual variation in feeding habits of Eumeces egregius, as indicated by proportions of individuals having empty guts (Study Area, Levy County, Florida) ... . . . . . . . . . 54

11 Seasonal change in size of eggs or follicles in female Eumeces egreglus (Study Area, Levy County, Florida). . 57

12 Average increase in snout-vent length from time of hatching for six groups of sibling Eumeces egreglus reared in the laboratory ............. 70

13 Geographic and sexual variation in size of adult Eumeces egreglus 


\section{INTRODUCTION}

The red-talled skink, Eumeces egreglus Baird, is a small, fossorial lizard locally distributed in the southeastern United States. The decision to undertake a study of the natural history of this species was prompted by several considerations. First, there was a scarcity of Information on the life history and ecology of this lizard, a scarcity characteristic of fossorfal reptiles in general. Furthermore, Wilfred Nelll had discovered a novel method of collecting this species which might, for the first time, solve the problem of obtaining adequate materlal for such a study. Finally, E. egreglus occurs chiefly In a peculiar type of terrain which supports some of the most fascinating and little-known ecological communfties of the Southeast.

The present paper deals largely with the ecological and behavioral aspects of the natural history of the red-talled skink. Some interesting information related to the problem of geographic variation was uncovered during the course of the Investigation; this will be presented at a later date. 
GENERAL METHODS

Efforts were made to obtain data on the life history and ecology of as many populations of Eumeces egreglus as time would allow. For intensive study a population of skinks inhabiting an area consiting roughly of the eastern one-fourth of Levy County, Florida, was selected. This area, hereinafter designated "the Study Area" (Fig. 1), is part of an extensive tract of sandhill country stretching from the Suwannee River on the north through parts of Alachua, Gilchrist, Levy, and Marion Counties southward to the northwestern corner of Lake County. Through this portion of their range, red-talled skinks appear to be especially abundant.

The Study Area was usually visited at 10-day intervals from September, 1959, to October, 1960. On these visits skinks were located and observed, ecological data were obtained, and a sample of specimens was collected for further examination and study. (Collecting methods are discussed in a later section.)

Ecological data were recorded for each capture. In most instances the temperature of the air was determined, as well as that of the soll in which the lizard was located and that of the soll $3 \mathrm{~cm}$ below ground level. The lizard's temperature was taken whenever practicable (see page 17). A Schultheis "quick-reading" thermometer was used for all determinations (see Bogert, 1949).

Most captured 1 lzards were k1lled, examined, and preserved, although some were kept in captivity for varying periods of time. Inftial 
PIG. 1. Locality records for Eumeces egreglus as of June, 1961. Generalized distribution of suitable habitat is indicated by stippling. 


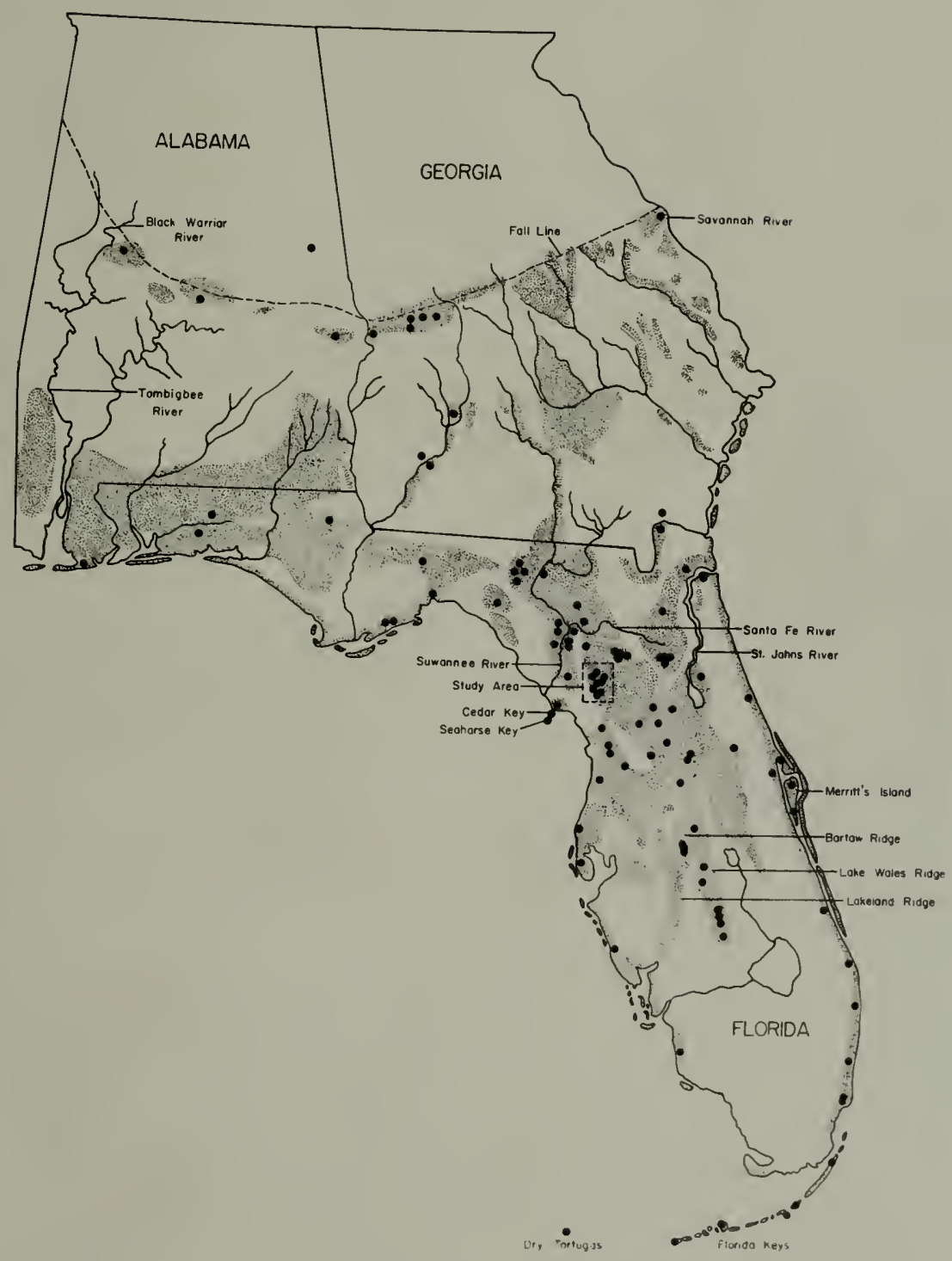


examination consisted of determining snout-vent length and tail length, noting characters likely to be altered by preservation, and searching for ectoparasites. Skinks were preserved in the conventional manner. After a month or more the specimens were remeasured. It was found that, on the average, 4 per cent shrinkage had occurred, necessitating distinction between measurements of freshly killed and preserved lizards.

The digestive tract of each lizard was examined and the food Items were Identified. Internal parasites were removed and preserved for later identification. Measurements of testes and ovarian and oviducal eggs were made with dividers. To measure a live skink, the specimen was put into a test tube and allowed to quiet down. By placing a millimeter scale under the tube, the desired measurement could be made. All data were recorded on McBee Keysort Cards printed specifically for use in this study. These were later coded.

Captive specimens were held in glass terraria filled to a depth of 3 to $8 \mathrm{~cm}$ with sand. They were fed mostly on laboratory-reared German roaches (Blatella germanica), termites (Isoptera), and mealworms (Tenebrio molitor). Food was supplied dally. Roaches were prevented from escaping by smearing a thin film of a vaseline-mineral oil mixture around the 1 nner edges of the terraria. Water was supplied to the captives in Syracuse watch glasses. 
Eumeces egreglus ranges throughout most of Florida and northward at least to the Pall Line in Georgia and Alabama (Fig. 1). There is only one record for an occurrence outside the Coastal Plain. Mecham (1960) reported the capture of a spectmen 3 miles northwest of Wadley In Randolph County, Alabama. This is approximately 38 miles north of the Fall line. It is possible that the species occurs sporadically in the lower Pledmont of both Georgia and Alabama.

Westward, the range extends at least to Hale County, Alabsma. Here I was able to collect one specimen from an area 8 miles east of Moundville. I suspect that the Black Harrior and Tombigbee Rivers mark the western boundary of the range. Considerable time was spent searching for specinens west of these rivers, particularly in the sandhill country of Washington County, Alabama, but none were found. The species has never been reported from South Carolina. The eastern limit of the range is apparently the Savannah River. 


\section{ECOLOGICAL DISTRIBUTION AND COLLECTING METHODS}

The most important ecological factors determining the dispersion of Eumeces egregius appear to be the aspects of soll structure and moisture conditions. Seldom is this species encountered where the soll Is not friable and well drained. However, there are differences between the habitats of the mainland and Insular populations which require separate consideration of these two groups.

On the mainland the skinks occur chiefly in sandhill and scrub assoclations and in xeric hammocks (Carr, 1940; Kauffeld, 1941; Telford, 1959; LeBuff, 1960). Sandhil1 assoclations, variously known as "longleaf pine--turkey oak," "high pine land," and "rolling sandy plne land," occur on many, if not most, of the very sandy, well-drained solls of the southeastern coastal plain (Fig. 2A). The dominant trees include longleaf pine (Pinus austral1s), turkey oak (Quercus laevis), and occaslonally bluejack oak ( $Q$. cinerea). Two wiregrasses (Sporobolus gracilis and Aristida stricta) are often the most important herbs. Frequently, much of the ground surface is almost completely bare. Scrub associations occur in Florida and along the coast of Alabama on certain excessively drained sands (Fig. 2B). The dominant trees are usually sand pine (Pinus clause) and a number of scrubby evergreen oaks. The shrubs, rosemary (Ceratlola ericoides), scrub-palm (Sabal etonia), and saw-palmetto (Serenoa repens), are often abundant. Ground cover is frequently sparse. Xeric hamock is generally less common; it is considered by Laessle (1942) to be the seral stage succeeding both scrub 
PIG. 2. Habitats of Eumeces egreglus. A. Vlew of a sandhill association in the Study Area, Levy County, Plor 1 da. Trees are turkey oak. About a dozen mounds of Geomys plnetis appear in the picture. B. A scrub association in Polk County, Florida. Saw-palmetto appears in the center foreground, rosemary in the left foreground, and sand pine in the background. C. The shoreline at the northern end of Cedar Key Alrstrip Island, Levy County, Florida, Red-talled skinks were taken by digging beneath the tidal wrack shown here. 


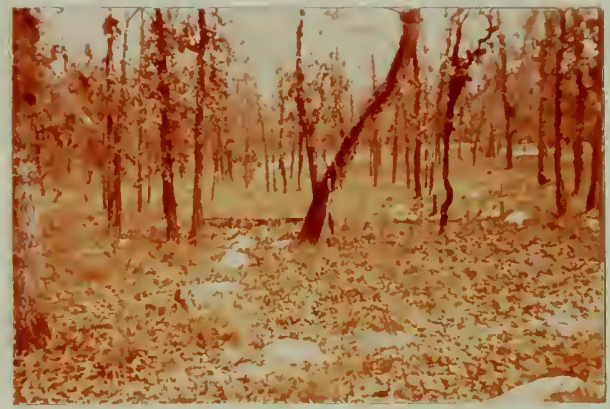

A

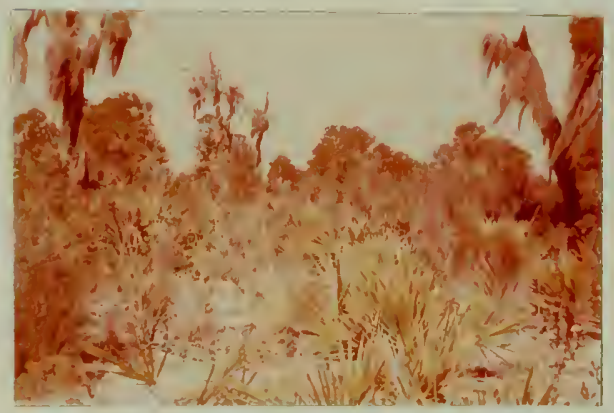

B

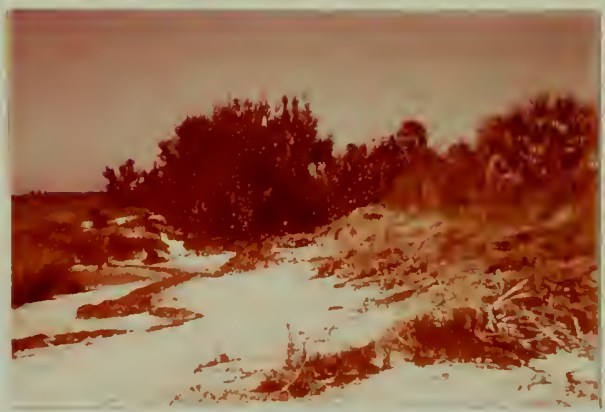


and sandhill associations. Live oak (Q. virginiana) dominates and ground cover 18 variable. For detalls concerning the nature of the plant associations referred to In this dlacussion, see Laessle, 1942 and 1958.

Other mainland collecting sites mentioned in the literature include "a road through a sandy, dry, open place" in Toombs County, Georgia (Jansen, 1954); under debris in sandy areas at Fort Benning, Georgia (Hamllton and Pollack, 1958); beneath wood chlps in areas of sandy ao11 in Richmond County, Georgia (Ne111, 1940). These records can probably be referred to sandhl 11 habitats.

Duellman and Schwartz (1958) collected specimens at Miami, Dade County, Florida, in "sandy areas near dwellings." The sandy solls around Miaml are usually deposits overlying the porus Miami oolite; such deposits are normally too shallow to support scrub or sandhill associations but may nevertheless be well dralned.

Mecham (1960) reported that the specimen mentioned earlier from Randolph County, Alabama, was collected "under a flat rock in a granitic outcropping of several acres extent." McConkey (1957) ment1ons a spec1men collected in a "very damp locality between a hamock and a flatwoods." I consider this occurrence highly unusual for this apecles. My experience in collecting this lizard from 72 different locallties leads me to suspect that within the range of the species all natural areas of 100 acres or more in extent favorable for the growth of aand pine, turkey oak, or rosemary are supporting red-tailed skink populations. This 18 contingent, of course, upon such areas having been 
zoogeographically accessible to the red-tail, and upon man's activities, or floods, not having resulted in their extermination from a given area.

In a paper presented by Wilfred $T$. Nelll at the 37 th annual meeting of the American Society of Ichthyologists and Herpetologists in 1957, he observed that the red-talled skinks in sandhill habitat near Silver Springs, Marion County, Florida, usually dwelt in the mounds of sand thrown up by "sand beetles" (Scarabaeidae, Geotrupinae), and that they were occasionally found in mounds of the gopher tortolse (Gopherus polyphemus) and the eastern pocket gopher (Geomys pinetis). He estimated that during winter and early spring about 70 per cent of the red-talled skinks in the area were living in beetle "push-ups" and burrows.

Raking through mounds and push-ups (Fig. 2A) of burrowing animals proved to be a highly effective method of collecting the skinks in sandhill associations. However, I found pocket gopher mounds more productive than beetle push-ups, of 422 specimens collected from sandhill associations, 326 were taken from pocket gopher mounds, and only 31 from beetle push-ups. Except for 1 ts absence in extreme southern Florida and in the Piedmont, Geomys pinetis ranges over almost exactly the same area as does the red-talled skink. This apparently reflects a similarity between the two forms in many of their ecological requirements, especially soil structure, and probably indicates similar patterns of dispersal for the two.

Skinks were also collected in sandhill habitats by overturning and raking beneath logs, boards, $t i n$, and other objects (28 specimens). 
Three specimens, the only ones encountered above ground, were found under fallen leaves. The remaining 3 represent chance encounters by persons digging in sand.

In scrub associations red-talled skinks were never found in Geomys mounds or beetle push-ups. Twenty-eight specimens were collected in scrubs, and all these were taken by raking under detritus with a potato rake. Most were located within $5 \mathrm{~cm}$ of the surface and were found under such things as dead palmetto fronds, decaying Spanish moss, and rotting logs. Scrub-collecting was most rewarding in areas where there was 1 ittle ground cover. For detalls concerning this metbod of collecting, see Telford (1959).

Red-talled skinks have been collected on the following islands: Dry Tortugas, Key West, Stock Island, Upper Matecumbe Key, BIg PIne Key, Indian Key, and Key Largo (Monroe County, Florida); from Cedar Key Airstrip Island and Seahorse Key in Levy County, Plorida; and from Merritt's Island, Brevard County, Florida. Some of the Monroe County records are old. The present distribution of the skink in the Florida Keys may have changed considerably over the years. Duellman and Schwartz (1958) suspect that "the specles probably ranges throughout the chaln of islands." I found specimens on Key West, Stock Island, and Key Largo. There is little doubt that the species still exists on Blg Pine Key. Many of the smaller keys are subject to complete inundation during severe hurricanes, however, and it is doubtful that a population would survive such an ordeal.

On the Keys the skinks frequent beaches and other areas where there is sufficient soll for burrowing. Carr (1940) noted their 
occurrence in piles of rock, debris, and wave-washed wrack and stated that in the Upper Keys they are abundant among rocks a few feet above the water on rallroad embankments. Duellman and Schwartz (1958) found them beneath stones in shaded, sandy areas on Key West and Stock Island. I found none under tidal wrack along the shorelines of the Keys. Nowhere In the Keys did the species appear to be abundant, either in February or June of 1960.

Red-tailed skinks were collected at Cedar Key Afrstrip Island by turning and digging beneath the tidal wrack. Most were found at or above the spring tide mark under wrack whlch was dry or only slightly molst. Three specimens were caught on the alrstrip itself by digging beneath small piles of dead grass. Attempts to collect the skink from Cedar Rey proper were unsuccessful, although conditions here seemed Ideal for its existence. The scrub surrounding the Cedar Key cemetery particularly warrants further investigation. The presence of the red-tall on Seahorse Key, some 3 miles out from Cedar Key, was first reported by Wharton (1958). During the present study, 18 specimens were collected on Seahorse Key, all of which were found associated with tidal wrack along the windward shore of the island. On Merritt's Island specimens were collected by digging under detritus on knolls in dry, scrubby flatwoods and in scrubs.

There is little doubt that red-talled skinks inhabit many more of the islands just off the Florida coast. There is every reason to suspect that they occur in the scrub on Marco Island in Collier County (Duellman and Schwartz, 1958), but I was unable to demonstrate their presence on either of two trips to that fascinating locality. The 18 lands around 
the mouth of Charlotte Harbor near Fort Myers likewise warrant investigation. 


\section{TEMPERATURE RELATIONSH IPS}

Under natural conditions the temperature of an active lizard does not necessarily correspond to the ambient air temperature but usually falls within a relatively narrow range which tends to be a generic or specific characteristic (Bogert, 1949; Bitch, 1956, 1958). Apparently, most lizards inhabiting temperate regions regulate their temperatures chiefly by their behavior. Those which have been most intensively studied are species which spend considerable time above ground, and thermoregulation in these depends to a large extent upon the relative amount of direct insolation absorbed. Thus, they bask in the sun when their temperatures fall below the optimal range and seek shelter when they get too hot. Little is known of the thermal relations of fossorial lizards. The following observations may be of value in this regard.

Thermoregulation in $\underline{E}$. egregius is not dependent upon the amount of direct sunlight recelved but seemingly upon the ability of the Individuals to move readily through the soll from one temperature stratum to another. This, I think, has a strong bearing on the frequent occurrence of $\underline{E}$. egregius in mounds of Geomys and sand beetles. While searching for red-talls in these mounds in sandhill associations, I often encountered other fossorial and semi-fossorlal reptiles. The crowned snake (Tantilla coronata) and the sand skink (Neoseps reynoldsi) were regularly found in the mounds. The worm lizard (Rhineura floridana) 
and scarlet kingsnake (Lampropeltis doliata) were each found on 3 occasions. Collecting in mounds was most profitable when mound temperatures were between $25^{\circ}$ and $34^{\circ}$ and somewhat higher than those of the soll beneath. These conditions obtain most frequently during the cooler months of the year on certain clear or partly cloudy days from about 10:00 a.m. until late afternoon.

The soil in the mounds is less densely packed than that about them, and dries more rapidly and thus heats more quickly in the sun than the surface soil. I suggest that during cool, sunny weather the mounds, when avallable, serve as convenient basking sites for such reptiles as those 11 sted and therefore afd in solving their thermoregulatory problems. During the hot weather which prevalls throughout most of the extreme Southeast from May through September, and during prolonged perlods of cool, cloudy weather, few animals of any kind were discovered in the mounds. Under these weather conditions it is unlikely that the mound temperatures would be more favorable than those in the soll below. I have already mentloned that, despite its occurrence in scrub habitat, E. egreglus was never collected in scrubs by raking through Geomys mounds, nor, for that matter, were reptiles of any sort. I can offer one possible explanation. Scrub soil (St. Lucie sand) is usually coarser (Laessle, 1958) and perhaps drains more readily than the solls supporting sandh111 assoclations. The surface layers of the St. Lucle solls may, then, warm more rapidly than the sandhill solls. Such being the case, the reptiles might be less inclined to frequent mounds in scrubs. 
I freyuently captured red-tailed skinks within a few seconds after they were first disturbed. In such cases I often measured the cloacal temperatures of the lizards. A total of 50 such records were obtained.

To supplement the fleld data on temperature relationships, I conducted laboratory experiments designed to provide information on temperature preferences. These experiments were conducted under the supervision of Dr. Alan D. Conger of the Blology Department, University of Florida, who suggested the design of the apparatus and was instrumental in procuring the equipment for its construction.

A sheet of brass $210 \mathrm{~cm}$ long and $1.7 \mathrm{~mm}$ thick was fashioned into a trough $8.6 \mathrm{~cm}$ wide and $3.6 \mathrm{~cm}$ long. A $140 \mathrm{~cm}$ section of the trough was completely enclosed in a box of $1 / 2-1$ nch plywood, the bottom and sides of which were provided with an inside lining of several layers of fiberglass insulation and one layer of aluminum foll. The top of the box was hinged and was lined on the Inside with one layer of fiberglass insulation. The trough was filled with alr-dry sand to a depth of $2.5 \mathrm{~cm}$. The $1 \mathrm{eg}$ at one end of the trough was immersed in ice water at $0^{\circ}$. Heat from a 200-watt incandescent 11 ght bulb was applied to the other end, and the apparatus was allowed to remain undisturbed for 2 hours. A stable temperature gradient ranging from $17^{\circ}$ to $80^{\circ}$ was produced along the enclosed portion. Up to within $60 \mathrm{~cm}$ of the heated end, or up to $36.5^{\circ}$, the gradient was almost uniform, changing at the rate of approximately $1^{\circ}$ per $4.2 \mathrm{~cm}$. Past this point the change became increasingly more rapid. 
Eight lizards, all sexually mature males of approximately the same size (43-45 snout-vent length), were used in the laboratory experiments. They were captured on April 21, 1961, at a site in the Study Area 6 miles south of Bronson, Levy County. Between experiments the lizards were kept in terraria and fed roaches and termites. Each individual could positively be recognized by peculiar structural features or marks. Two experiments were conducted on each of the following days: May 6,13 , and 17, 1961, according to the following procedure.

The 8 lizards were randomly divided into 2 equal groups. The skinks in one group were distributed at random in the trough, along which the temperature gradient had been produced and allowed to stabilize. The lizards usually burrowed into the sand within a few seconds. The box was then closed and left undisturbed for 90 minutes. The lizards were from all indications sexually inactive and had displayed no aggressive tendencies as captives. There was no reason to assume that under the circumstances, they would not tend to distribute themselves in accordance with their preferred temperatures. At the end of the 90-minute pexiod the box was reopened and the temperature of the sand was determined at $5 \mathrm{~cm}$ intervals and recorded. To restrict subsequent movement of the lizards, pieces of cardboard were inserted into the sand at $10 \mathrm{~cm}$ intervals, at right angles to the long axis of the trough. The lizards were located and removed, and the 1dentity of each was recorded along with the temperature corresponding to the posttion in the trough at which the individual had been found. The experiment was then repeated using the other group of animals. 
Field observations and laboratory results are shown in Fig. 3. Temperatures of lizards taken in the field ranged from $16^{\circ}$ to $36^{\circ}$. Those with temperatures below $24^{\circ}$ were noticeably sluggish in their movements and were taken when soil conditions were such that maintenance of higher temperatures would seemingly have been impossible. It soon became evident that if the fleld observations were to be meaningful, they would have to be grouped into two classes. Some were made on days when the lizards could select from a relatively wide range of temperature levels in the soil, others on days when it seemed that they could not. Accordingly, in Pig. 3, the observations made on days when the air temperature was $25^{\circ}$ or over are distinguished from those made during cooler weather. Usually, when the air temperature was $25^{\circ}$ or above, most sunlit Georny and beetle mounds contained some soil in the $34^{\circ}$ to $36^{\circ}$ range.

Based on the former class of observations, it appears that the preferred temperature range for E. egregius 11 es between $26^{\circ}$ and $34^{\circ}$. The mean for these observations is $29.5^{\circ}$. The results of laboratory experiments indicate a somewhat higher range. The three occasions on which individuals were found in the $16^{\circ}$ to $18^{\circ}$ range can probably be attributed to escape attempts. In each of these cases the lizard was found lying against the cold end of the trough with its snout in the corner. If these are excluded from consideration, the mean of the observations is $31.2^{\circ}, 1.7^{\circ}$ higher than the corresponding mean calculated from the field data. It is possible that these differences are due to faulty technique, or to inadequacy of the samples involved. The possibility of seasonal differences in temperature preference should 


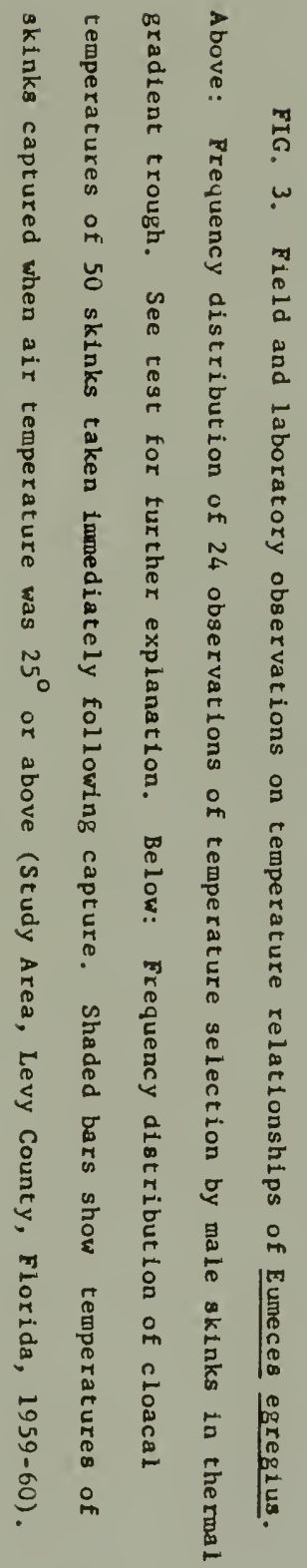




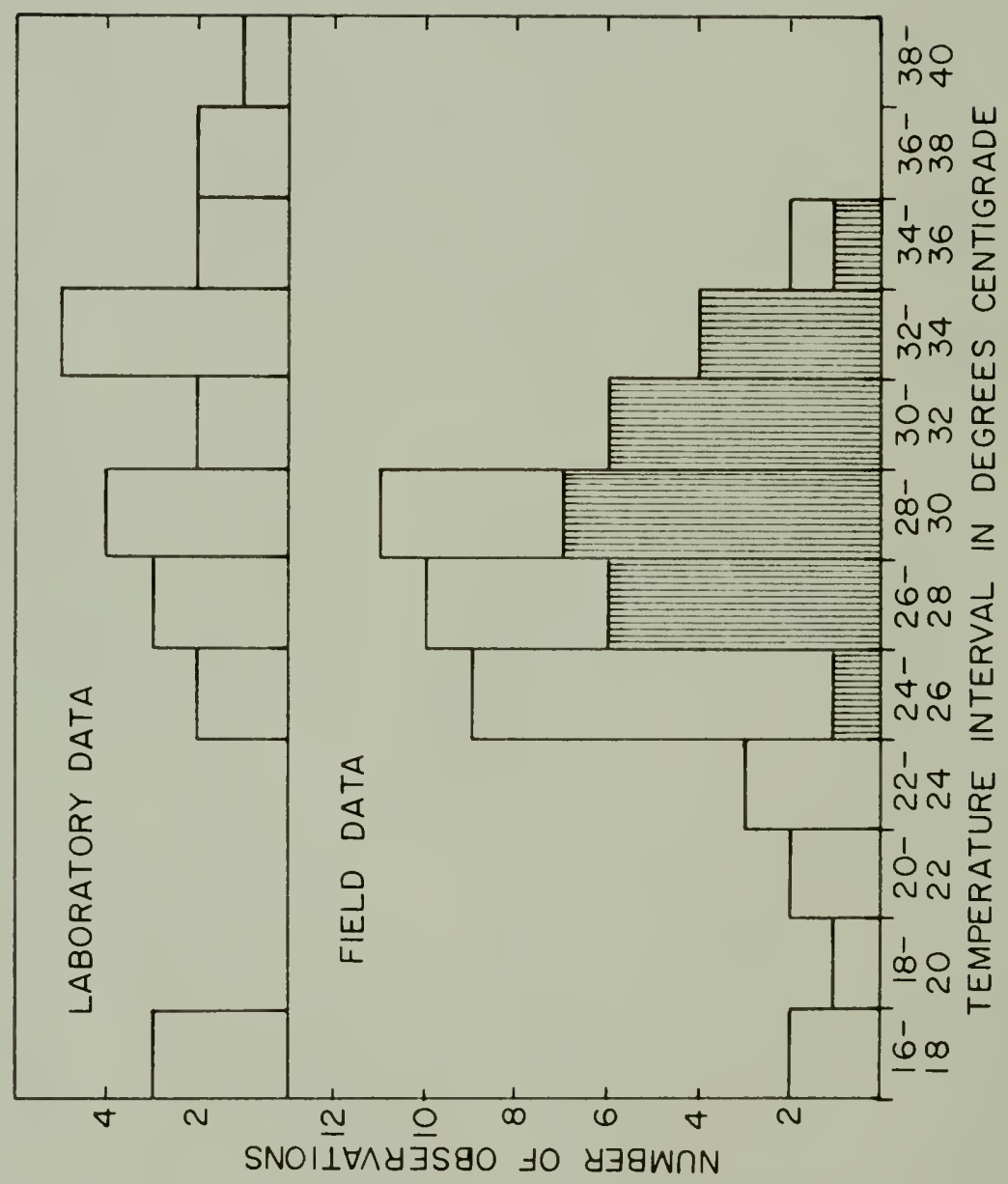


not be discounted. The laboratory experiments were conducted in May, whereas most of the field observations were made from October to mid-April.

There were no detectable differences among the Individuals used In the laboratory tests with regard to temperature preference. Differences were undoubtedly present but were probably slight, since the test animals were all of the same sex, of approximately the same size, and from the same population.

There seems to be little doubt that, despite the incongiatencies, the preferred temperature for $\underline{E}$. egregius is lower than that for the Great Plains skink (Eumeces obsoletua) or for the five-lined skink (Eumeces fasciatus) determined by Fitch (1956) to be $34.0^{\circ}$ and $33.0^{\circ}$, respectively.

The laboratory method employed in this study, or a modification thereof, appears to be entirely satisfactory as an aid in studying the temperature relationships of almost any fossorial reptile. Such forms as Rhineura floridana constitute exceptions, since they desiccate rapidly in dry soll. The method would seem to be particularly well suited to studies of a comparative nature. I suspect, for instance, that gravid female E. egregius tend to occupy warmer soll strata than do other individuals. This method could be used to test this hypothesis. Geographic variation in temperature preference, as well as differences due to stage of development could perhaps be detected. 


\section{LOCOMOTION}

Several kinds of locomotion are used by red-talled skinks. A foraging individual progresses in jerky, erratic fashion, using both front and hind limbs, which are reduced in size and relatively feeble. Occasionally the skink will press 1 ts hind legs back against the tail and glide for a short distance, the body and tail exhibiting slight lateral undulatory movements. While moving in this manner, the lizard frequently uses its front legs to effect changes in direction. They may also be used to pull the body along.

Red-tailed skinks are capable of rapid submergence in loose so11 and are remarkably adept at "sand-swimming," although not nearly so proficient at this activity as Neoseps reynolds1. Plunging its snout into the soil, the skink presses the front limbs against the body, pushes with the hind limbs, and, with body and tail undulating laterally, disappears beneath the surface. It then uses undulatory "swimming" movements to progress through the soll. There is no indication that the limbs play any role in this type of locomotion. The soil may be entered at almost any angle; a skink that has been startled normally enters at a greater angle than is usual in unhurried submergence.

On a relatively hard-packed surface, a frightened red-tailed skink may wriggle away like a small snake. Rapid sidewise undulations of the body and tall augmented somewhat by the limbs drive the lizard forward. This type of locomotion is sometimes seen in an individual pursuing fast-moving prey. 
From the standpoint of locomotion, then, Eumeces egregius appears to occupy a position somewhere between the generalized skinks, e.8., Eumeces fasciatus, and the highly specialized burrowers like Neoseps reynoldsi. 
FOOD HABITS

The sole reference to food habits of Eumeces egregius is that of Hamllton and Pollack (1958). They examined the digestive tracts of 36 specimens, 23 of which contained food (20 from Ft. Benning, Ceorgia, and 1 each from St. Petersburg, Key West, and Bonita Springs, Florida). They recorded the following food items (figure following item indicates number of specimens in which item was found): ant, 5; spider, 5; Orthoptera, 5; Coleoptera, 4; Isoptera, 2; Hemiptera, 2; mite, 1 ; Lepldoptera larva, 1; pseudoscorpion, 1; Neuroptera (ant 11on), 1; and enchytrid, 1 .

Among $460 \mathrm{specimens}$ preserved during the present study, 257 contalned food. I could detect no differences between sexes nor among the various size-classes with regard to relative proportions of major classes of food thems present in the alimentary tracts. There likewise appeared to be no outstanding differences among the varlous mainland populations in this regard.

The food habits of the populations on Cedar Key Airstrip Island and Seahorse Key appear to be rather spectalized and lizards from these places are therefore considered separately. I did not obtain data on food habits of populations in the Florida Keys (Monroe County).

Roaches, spiders, and crickets were by far the most Important food 1tems for mainland lizards, occurring in $41.0,36.2$, and 20.2 per cent of the tracts, respectively (Table 1). The splders were mostly small 
TABLE 1. Freyuency of occurrence of food items in digestive tracts of Eumeces egregius.

\begin{tabular}{|c|c|c|c|}
\hline Food 1 tems & $\begin{array}{l}\text { Mainland } \\
\text { habitats } \\
\quad(232)\end{array}$ & $\begin{array}{l}\text { Cedar Key } \\
\text { A1rstrip Island } \\
\text { (17) }\end{array}$ & $\begin{array}{c}\text { Seahorse Key } \\
\text { (8) }\end{array}$ \\
\hline Roaches & 41.9 & & \\
\hline$\frac{\text { Cariblatella lutea }}{\text { Arenivaga }} \frac{\text { floridensis }}{\text { Unidentified }}$ & $\begin{array}{r}18.5 \\
3.9 \\
18.5\end{array}$ & & \\
\hline Spiders (mostly Lycosidae) & 36.2 & & \\
\hline Elaterid beetle larvae & 4.7 & & \\
\hline Beetle larvae (other) & & 5.9 & 50.0 \\
\hline Beetle adults & 1.7 & & 12.5 \\
\hline Lepidoptera larvae & 0.8 & & \\
\hline Centipedes & 1.3 & & \\
\hline Scorpions & 0.8 & & \\
\hline Termites (winged) & 0.4 & & \\
\hline Termites (workers) & 0.4 & & \\
\hline Locustid grasshoppers & 1.3 & & \\
\hline Ant lions & 0.4 & & \\
\hline Ants & 0.4 & & \\
\hline Earwigs & 0.4 & 11.8 & 75.0 \\
\hline Amphipods & & 100.0 & \\
\hline Isopods & 0.4 & 5.9 & \\
\hline Fiddler crab & & 5.9 & \\
\hline Unidentified insects & 15.5 & & \\
\hline
\end{tabular}

${ }^{a}$ Figures in table are percentages of total number of individuals containing food in each group. These totals are shown in parentheses. (See also Table 2 and PIg. 7.)

${ }^{b}$ Sandhil1 and scrub associations. 
wolf spiders (Lycosidae). Roaches were of several species, Cariblatella lutea being the most important and occurring in at least 18.5 per cent of the tracts. Probably, most of the roaches listed as "unidentified" belonged to this species also. Cariblatella lutea is abundant in sandhill habltats. At night it crawls on the ground surface and among the leaves and branches of the turkey oak trees. During the daylight hours most probably take shelter in underground burrows of Geomys, gopher tortoises, beetles, and other such animals and in holes resulting from the decay of large roots. I never encountered this species in and about rotting logs, where other roaches are common, but I found numerous individuals in Geomys burrows.

The roach, Arenivaga floridensis, was eaten by 3.9 per cent of the mainland lizards. This is a fossorial insect and is highly adapted for such an existence, being able to move rapidly through the soll in much the same manner as do mole crickets (Gryllotalpinae). It is occastonally found in the mounds of Geomys and sand beetles.

Although termites and elaterid beetle larvae are readily eaten by captive skinks and are abundant in sandh1ll and scrub communities, they play a relatively minor role in the diet of Eumeces egregius, occurring in, respectively, 0.8 and 4.7 per cent of the tracts. Grasshoppers occurred in only 1.3 per cent.

These data Indicate that $\underline{E}$. egreglus spends little time above ground, at least in relatively exposed situations. The only food items definitely suggesting surface activity were the grasshoppers. The high incidence of lycosid splders, crickets, and the less speclalized roaches in the diet may be indicative of what I consider to be an 
important feature of the dally routine of the lizards, namely, that of prowling about in pre-existing subterranean passages in search of food. If most of the skinks' hunting is done in that fashion, termites and elaterid beetle larvac would be largely unavallable as food items, since they live in burrows much too small to accomodate the red-tails. The food habits of $\underline{E}$. egreglus contrast sharply with those of Neoseps reynoldsi, a fossorial skink coexisting with the red-tail in parts of central Florida. Termites and elaterid beetle larvae const 1 tute a large proportion of the food of this species (S. R. Telford, Jr., unpublished data). Neoseps is a more highly specialized burrower than E. egregius and is correspondingly better equipped to locate these insects and use them as food.

Seasonal variation in food habits is indicated for the red-talled skinks inhabiting the Study Area. In Table 2 the food data on specimens collected in the Study Area are grouped according to periods roughly corresponding to autumn, early winter, late winter, and spring. Roaches are eaten more frequently during the winter months than in autumn and spring. The opposite is noted for crickets, which are least important as food items during the winter months. My observations indicate that this seasonal variation in food habits reflects changes in the relative abundance of the prey, their patterns of activity, or both, rather than shifts in microhabitat or food preference on the parts of the lizards.

The diet of the skinks collected on Cedar Key Alrstrip Island consisted almost entirely of crustaceans. Amphipods occurred in every tract examined. These animals were present in large numbers in the 
tidal wrack under which the skinks were collected. One specimen had eaten a small fiddler crab, and another, an isopod. The only non-crustaceans were 2 earwigs, 1 in each of two tracts, which together made up 11.8 per cent of the total, and a beetle larvae in one tract.

TABLE 2. Frequency of occurrence of food items in digestive tracts of Eumeces egregius by season (Study Area, Levy County, Florida).

\begin{tabular}{|c|c|c|c|c|}
\hline & \\
\hline & \multicolumn{4}{|c|}{$\frac{\text { Period and per cent of specimens containing food" }}{\text { "Rarly "Late }}$} \\
\hline & Sep, Oct, Nov & $\begin{array}{c}\text { Dec, Jan } \\
(44)\end{array}$ & $\begin{array}{l}\text { Peb, Mar } \\
\text { (52) }\end{array}$ & $\begin{array}{c}\text { Apr, May } \\
(8)\end{array}$ \\
\hline Roaches & 31.4 & 54.6 & 50.0 & 12.5 \\
\hline Cariblatella lutea & 14.3 & 36.4 & 26.9 & \\
\hline Arenivaga floridens is & 2.9 & & 3.8 & 12.5 \\
\hline Unidentified & 14.3 & 18.2 & 19.2 & \\
\hline Spiders (mostly Lycosidae) & 40.0 & 36.4 & 36.4 & 12.5 \\
\hline Crickets & 31.4 & 9.1 & 19.2 & 50.0 \\
\hline Beetle larvae & 2.9 & 2.3 & 5.8 & \\
\hline Beetle adults & & & 1.9 & \\
\hline Lepldoptera larvae & 2.9 & & & \\
\hline Centipedes & & & 1.9 & \\
\hline Scorpions & & & 1.9 & \\
\hline Termites (winged) & & 2.3 & & \\
\hline Grasshoppers & & & 3.8 & \\
\hline Ant lions & & & 1.9 & \\
\hline Ants & 2.9 & & & \\
\hline Diptera adults & & 2.3 & & \\
\hline Unidentified insects & 28.6 & 13.6 & 5.8 & 37.5 \\
\hline
\end{tabular}

${ }^{a}$ Figures in table are percentages of total number of individuals containing food in each group. These totals are shown in parentheses. (See also Pig. 7.) 
The specimens examined from Seahorse Key were collected under what appeared to be the same circumstances as those from Airstrip Island, 1.e., along the shore under tidal wrack which teemed with amphipods. However, no amphipods were found in any of the 8 specimens collected whose tracts contained food. Earwigs, on the other hand, occurred in a 11 but 2 of the tracts, and a small scarab beetle appeared in 1 stomach. I cannot explain the absence of amphipods in the tracts of these specimens. 


\section{FEEDING BEHAVIOR}

Fitch (1954) described the feeding behavior of Eumeces fasciatus in considerable detail. I was unable to observe $\underline{E}$. egregius in the act of feeding in nature, but, based on numerous laboratory observations, I conclude that there are few fundamental differences between its feeding behavior and that of E. fasciatus. Live German roaches were kept In the lizards' terraria almost all the time. The roaches usually remained hidden beneath accumulations of detritus on the surface of the sand. A lizard, upon making its appearance on the surface, would begin to crawl about, probing beneath the detritus with its snout. When a roach was flushed from cover, a lively chase usually ensued. Upon being captured, smaller roaches were chewed for a few seconds and swallowed entire. Before swallowing adult roaches, the lizards frequently pulled off their legs and wings.

Termites, when placed in the terraria, were plucked from the surface, chewed once or twice, and swallowed. Ant lions (Myrmeleonldae) were eaten by the captives if they were sighted before they worked their way into the sand. At least once an ant lion was recovered from beneath the surface and eaten. A skink was prowling on the surface in a terrarium in which several ant lions had built their characteristic pits. Suddenly he stopped and peered intently into one of these pits. He quickly plunged his snout into the sand at the bottum of the pit, retrieved an ant 11 on, and chewed and swallowed it. Apparently the 
lizard had detected the insect's presence by the shifting of the sand at the bottom of the pit.

In hatchlings feeding is accompanied by much movement of the tail. This behavior becomes greatly exaggerated if the prey is active and difficult to subdue, or if the lizard is disturbed by the presence of another Individual. It becomes less pronounced with Increase in age. Swallowing a relatively large food item is accompanied by a considerable amount of head and neck movement. The head is nodded up and down, while the neck is flexed latexally. Such actions tend to force the food into and down the esophagus.

Some skinks become tame enough to accept food from one's fingers. They take not only freshly kllled insects held before them, but also fragments of dissected insects, after first touching these with theix tongues. 


\section{ANNUAL CYCLE OF REPRODUCTION AND ACTIVITY}

\section{Courtship and Mating}

The peak of courtship and mating activity in Eumeces egregius occurs in fall and winter, not in the spring as in most other species of lizards inhabiting temperate North America. Then the sexually mature males become brightly suffused with yellow, orange, or reddishorange along the lower sides of the body and usually on the lower lips, chin, and on the sides of the neck (Fig. 4A). In an occssional individual the entire venter is so suffused ( $\mathrm{Fig}$. 4B). In dark individuals the yellow-orange shades tend to be stronger than in lighter ones. This coloration normally persists in the males through the perlod of sexual inactivity but gradually becomes less pronounced. Showy colors are commonly exhibited by male members of the various species of Eumeces. The current concensus appears to be that such coloration serves, along with odor, as an important means of sex recognition (see Evans, 1959).

The suffusion disappears in preserved specimens. After 24 hours in 10 per cent formalin the suffused areas become rose-colored and fade completely after a month in 30 per cent isopropyl alcohol.

In the Study Area in 1959 mating apparently began some time during September or October. Males collected during October had enlarged testes (Fig. 5), and in some the orange suffusion had begun to intensify. Three mature females collected during the first week of this 


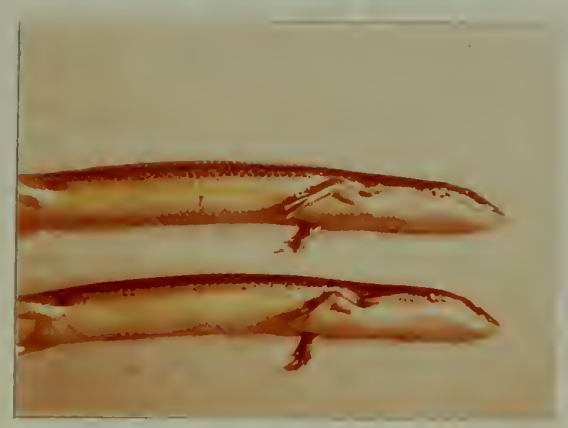

A

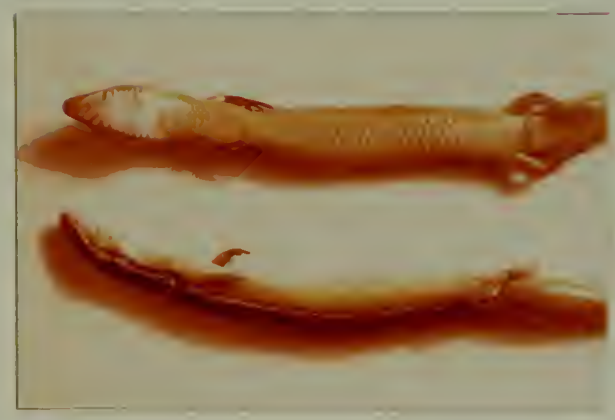

FIG. 4. Breeding coloration in male Eumeces egregius. Usually, this coloration is confined to the sides of the body and neck and to the lower lips and chin as in A above (upper from Levy County, Florida; lower from Putnam County, Plorida). In an occasional individual the venter is suffused with breeding coloration, as in those shown in $B$. Both these specimens are from the Plorida Keys, where this condition is most freyuently encountered. 


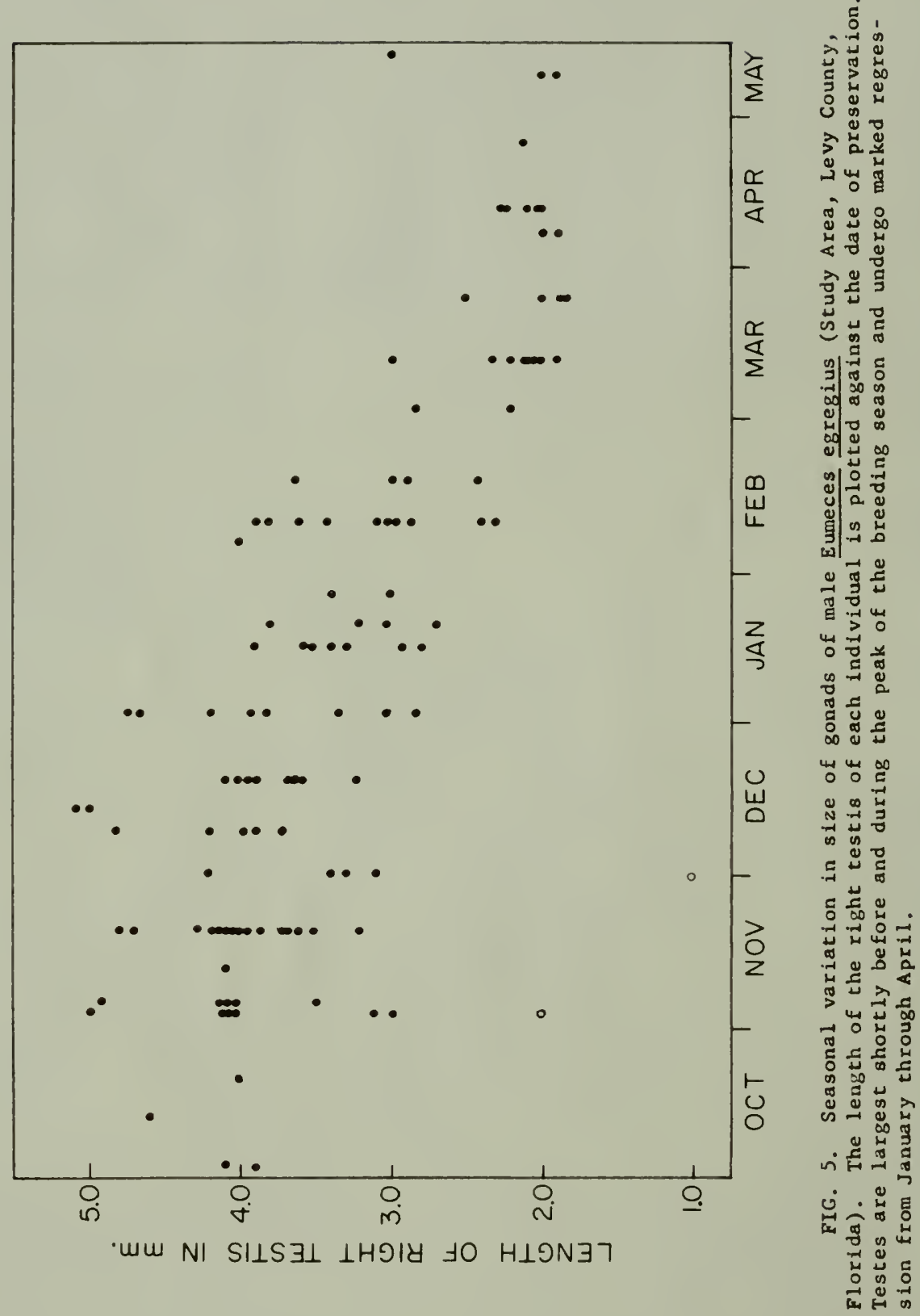


month, however, had apparently not mated (see page 43). Mated females were collected on November 3, and by mid-December, all mature females taken had mated. Mating activity in this population probably continued through January and into February. The testes of the males in the Study Area were most enlarged during November and December and became progressively smaller thereafter.

Among captive mature lizards collected in the Study Area during September, 1959, the first signs of sexual activity were observed on October 8. On this date a male unsuccessfully attempted to mate with one of two females being held in the same terrarlum. The first successful mating was not known to occur until November 6 . Matings among captives were most common during December.

All evidence indicates that fall and winter mating is the rule for most of the other populations of $\underline{\underline{E}}$. egreglus. Sexually active males were collected from the Fall Line Hills region of Georgia in September. It is likely that mating begins somewhat earlier here than farther south. Females which had recently mated were collected in Florida from the Lake Wales Ridge in January and February and from the lower east coast in Martin County in February. The situation in the Florida Keys is not clear. On February 2, 1960, six mature males were collected at Key West. All these specimens were brilliantly suffused (F1g. 4) and appeared to be at a peak of sexual readiness. Babbitt (1951) reported a mating between two red-talls at Key West on March 13, 1946. It is possible that the mating period either is more prolonged or reaches a peak later in the season in the populations inhabiting that area. 
Babbitt's brief account has been the only published record of courtship and mating in Eumeces egregius. In it he stated that the entire procedure lasted 25 minutes, of which 5 minutes were spent in copula. He did not describe details, nor did he mention the position assumed by the copulating lizards.

I witnessed courtship and mating behavior among captive specimens on at least 25 separate occasions, involving lizards from almost every portion of the range of the species. The sequence of major events was the same in every instance, although the timing was variable. There appeared to be no trenchant geographic variation in the manner in which courtship and mating was accomplished. Furthermore, individuals from a particular geographic area mated equally as readily with those from other localities as with lizards from the same localfty, regardless of differences in morphology and coloration.

My observations indicate that in this species scent is not only the most important factor causing sexual excitement in the male, but also in enabling him to locate and recognize a female. Males freyuently become sexually aroused almost 1mmediately upon being placed in terraria with females, even if the latter are completely buried in the sand. The behavior of a male so stimulated is distinctive. The basal portion of the tail shows rhythmic, lateral vibrations. When the tall is short and stubby, it may vibrate along its entire length. At times these vibrations become so intense as to cause the entire body to shake. In the intervals during which the tail is not actually vibrating, peristaltic-1ike waves of muscular activity run through the basal half, while the tail itself may show slight undulatory movement. At times 
these may be accompanied by a moving of the pelvic region in a circular manner against the substrate.

A sexually excited male progresses slowly and deliberately, his body and legs yuivering almost imperceptibly. Any movement on the part of another lizard will immediately attract his attention and cause him to investigate. If the other 11 ard is sexually immature or is a member of another specles, the aroused male approaches to within 2 or 3 centimeters, then turns away. If it is another male, he may avoid it entirely or display aggressive behavior (see below). In case it is a sexually mature female, the male moves up quickly and touches his tongue to the nearest part of her anatomy. Any slight movement by the female at this time will cause him to seize her in his jaws at the most convenient spot. The female nearly always makes an apparent effort to escape, which may be resolute or somewhat half-hearted. The resolute attempt, which is usually frantic, is invariably successful, and in most cases probably indicates a lack of physiological predisposition on her part toward sexual activity. Such a female, on making good her escape, twitches and waves her tall excltedly and may yulckly disappear beneath the surface.

A female sufficiently motivated intrinsically and extrins $1 c a 11 y$ struggles feebly for a moment and begins to crawl slowly forward. Her body begins to twitch at intervals of approximately one-half second. The male at this time may tug at the female and actually drag her around for a moment. Sooner or later she turns her head toward the male and begins to crawl in a tight, circular path. 
Meanwhile, if the male had inftially chanced to seize her by a fold of skin on either side of the anterlor half of the trunk, he retains this original grip. If not, at some point in the preliminary maneuvering he will shift his hold to this position, whereupon he begins vigorously stroking the back of the female with his front foot nearest her. These stroking motions are also displayed by male Neoseps reynoldsi during courtship and mating (Telford, 1959). The female continues to crawl in a circular path, her body twitching somewhat convulsively, while the male half-crawls and half-drags himself along beside her, persistently stroking her back. Occasionally the male brings a hindfoot into play, brushing it over the female's pelvic region. The crawling on the part of the female lasts from one-half to ten (usually from two to five) minutes. When she stops, the male curves his body sharply, brings it over that of the female, and begins to maneuver the posterior portion in such a manner as to bring the undersurface of his pelvic region into juxtaposition with that of hers. Normally the female ralses her pelvic region and arches her tail slightly, thus facilitating assumption of the mating position. The male usually coils his tall from one to one and one-half times about the basal portion of her tall before everting the appropriate hemipenis and inserting it into her partially open vent. Copulating red-tailed skinks are shown in Fig. 6.

Barring some rather severe disturbance, this position is maintained for 12 to 50 (usually for about 25) minutes. During this time there is little noticeable activity on the part of either individual, except for an occasional twitching of the female accompanied by stroking by the 


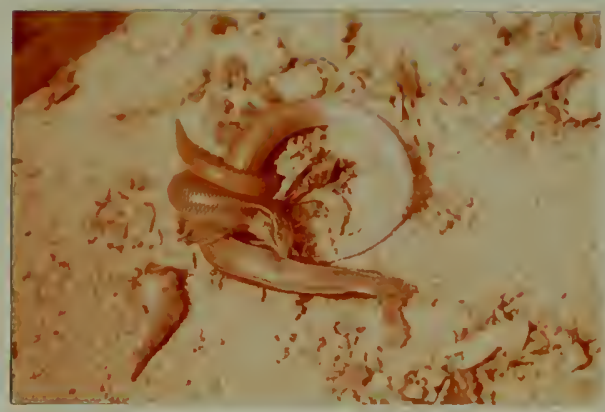

FIG. 6. Mating of Eumeces egregius. In this species the male grasps the female immediately behind the front leg and directs his body first over then under that of the female.

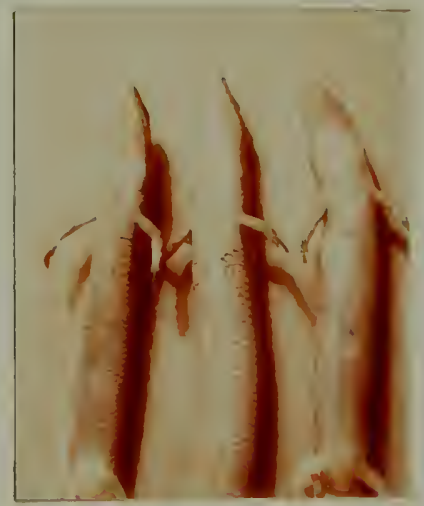

FIG. 7. Mating scars on female Eumeces egregius. These characteristic V-shaped scars, located immediately behind the front legs, result from the bites of the males during mating. The lizard on the left shows one scar; the one in the middle, three; and the one on the right, two. 
male. Occasionally, when warm sunlight falls upon the copulating lizards, the males sppear to fall asleep in this position. While in copula the lizards pay little attention to their surroundings, even to the point of allowing themselves to be picked up and handled. The entire courtship and mating procedure may last up to 80 minutes.

The female as a rule terminates the act of coitus by crawling slowly forward, whereupon the male releases his hold, and the two go their separate ways. The male moves little or remains perfectly still for as much as a minute or more after copulation, all the while holding his pelvic region off the sand while inverting his hemipenis. He may then forage for awhile or may at once disappear beneath the surface. On several occastons copulation did not occur, even though the initial phases of courtship were completed in what appeared to be an orthodox manner. Such instances usually involved a small male and a large female. On one occasion a male $42 \mathrm{~mm}$ in snout-vent length tried to mate with a female $58 \mathrm{~mm}$. The point in courtship was reached where the male had, after several unsuccessful attempts, managed to seize the female by the left side, and she had begun to crawl in a circular path. This went on for about 15 minutes, during which time the male had on several occasions brought his body across that of the female and attempted to achieve vent-to-vent contact. Each time she would raise the base of her tail slightly, but apparently, correct positioning was never effected. She finally began to burrow into the sand, whereupon the male released her.

The followlng notes were made on November 6,1959 , on the courtship and mating of a pair of captive red-tailed skinks collected from 
the Study Area on October 4. The male was $43 \mathrm{~mm}$ in length and the female, about $46 \mathrm{~mm}$. The air temperature was $24^{\circ}$ and the temperature of the surface of the sand in the terrarium, $27^{\circ}$. The terrarium was in direct sunlight.

10:55 a. m. A male and female skink appeared on surface of sand; the male was intent upon catching the other. Female moved slowly about on surface. After 15 seconds male overtook and seized her by right side of neck and immediately began "stroking" or "scratching" her back with his left front foot. This lasted about 80 seconds with female crawling continuously.

11:00 a. m. Female began twitching posterior part of body, turned toward male and began to crawl in tight circle, body jerking slightly every $1 / 2$ second or so.

11:05 a. m. Female was st11l crawling in circle with male holding on tightly, trying to keep body parallel with that of female and occasionally to straddle her.

11:06 a. m. Male was breathing hard and fast. Female stopped crawling, and with body still in circle, began twitching pelvic region about three times per second.

11:07 a. m. Male brought body over that of female, curved and twisted it so as to bring vent into contact with hers. Female raised tail in apparent effort to cooperate. Male colled tal1 about that of female.

11:08 a. m. Copulation apparently began. Both an 1mals were quite st111 except for slight twitching movements on part of female, 
these occurring at intervals of about 5 seconds. Each time female twitched, male vigorously stroked her back. 11:09 a. m. Both animals very still.

11:14 a.m. Female twitched twice, male stroked her for about 3 seconds.

$11: 20$ a. m. Female struggled for moment, then became st111 except for an occasional twitch. Male didn't stroke this time.

11:23 a. m. Female began to move around, and tried to bite male. After a few seconds she freed herself from male and dug into sand. Male remained quiet holding hind quarters off of sand while inverting hemipenis.

11:24 a. m. Hemipenis completely inverted. Male burrowed into sand. After each mating act a V-shaped scar is left on the underside of the female (Fig. 7). This scar, resulting from the male's bite, remalns clearly defined for from 1 to 2 months afterward, becoming decreasingly conspicuous thereafter. Often a trace of this scar can be seen for as long as 6 months following copulation.

of 126 female skinks collected having mating scars, ninety had only 1 scar, the rest 2 or more. More than 2 were found on 5 specimens, and on 1 of these, 4 were clearly distinguishable. Considering only scarred specimens, there appeared to be no correlation between the number of scars per female and the date of collection relative to the height of the mating season. Also, I could establish no correlation between the number of scars and the size of the individual.

Mating scars occurred on the left sides of $89 \mathrm{specimens}$ and on the right sides of 71. Included in these totals were 34 individuals which 
had acyuired the scars on both sides. There was no correlation between geography and scar location.

It appears, then, that most females mate only once per season. Among captives, I observed no reluctance on the part of a female skink to copulate a second time but after this there was a distinct tendency in most instances for the individual to avold males. Only one captive female mated 28 many as 3 times.

In the position they assume during copulation, red-tailed skinks may be unique among North American species of Eumeces. Every account of mating in other North Amerlcan forms describes the male as grasping the female, usually by the neck, and imnediately directing his body under, not over, that of the female. Mating has been described for E. fasciatus (Fitch, 1954), the broad-headed skink (ㅌ. laticeps) (Goin, 1957), the prairie skink (E. septentrlonalis) (Breckenridge, 1943), and E. obsoletus (Smith, 1946).

The copulatory position in Neoseps reynoldsi (Telford, 1959) may be similar to that in $\underline{E}$. egregius. Moreover, Telford informs me that he has seen mating scars on female Neoseps which are similar to those on female red-tails. Upon examining a number of specimens of the little brown skink (Lygosoma laterale), I noted V-shaped scars on the undersides of several individuals. These were located just behind the forelirubs, and I assume they were mating scars. This may indicate that mating positions are similar for $\underline{L}$. laterale and $\underline{E}$. egregius.

I never witnessed sexual activity among red-talled skinks in the field, althougb I spent many hours at the height of the mating season in areas where the skinks were extremely abundant. This raises the 
question as to where these activities normally take place. A consideration of the mating act itself may offer some clues. I consider one of the most significant features of the act to be the prolonged period of time during which the individuals are actually in copula. In many lizards, if not most, this period lasts no longer than a few minutes. Probably, individuals so engaged are considerably more vulnerable to attack by predators than if they are separate and foraging. This would be especially true if mating took place in relatively exposed places. Following this line of reasoning one can speculate that $\underline{\text { E. egreglus }}$ normally mates in sheltered situations such as the burrows and passageways constructed by Geomys and Gopherus. It is possible that the mating observed by Babbitt at Key West was unusual for the species. Another possibility is that, owing to the specialized habltats occupied by the skinks on the Florida Keys (see page 13), matings in the open are more common there.

While I noted considerable variation from time to time in the details of the process, every instance of courtship and mating I observed involved the same sequence of behavioral events. The sexually excited male, characterized by his quivering body and legs and intermittently vibrating tail, nosed and licked the female, then seized her somewhere on the body or tall. The female, if willing to mate, eventually responded by turning toward the male and crawling in a tight, circular path. Invariably she jerked or twitched her body from time to time during the proceedings, and invariably the male stroked her back. A similar mating position was assumed in every case, with the male grasping the female on the side of the anterior portion of her 
trunk while arching his body over hers and curving it back under in such a manner as to achleve vent-to-vent juxtaposition. In conclusion It may be said that courtship and mating in Eumeces egregius is for the most part a highly stereotyped affair.

\section{Homosexual Behavior}

Homosexual behavior was observed only among female $\underline{E}$. egreglus. In the fall of 1960 , six female lizards, each of which had laid fertile eggs during the previous spring, were being held in a terrarium. Only one of these six, a large Individual from Highlands County, Florida, had been in contact with a male subsequent to the nesting period, having been taken from the terrarium and allowed to mate with a male from Polk County, Florida, on October 27. Following this mating she was Immediately put back with the other females.

At $11: 00 \mathrm{a}$. m. On November 14 this 11 zard was seen attempting to "copulate" with one of the smaller females. They had assumed a pos1tion which, upon superficlal examination, seemed identical in every respect with that in the normal mating act. As far as I could tell, the only behavioral feature lacking, except for actual penetration, was the back-stroking activity normally displayed by the male member of a copulating palr. The smaller female was apparently making every attempt to effect coltus and was even twitching her body in the prescribed manner. For $20 \mathrm{minutes}$ the 1 izards remained in this position. Finally the smaller one began to crawl forward, whereupon the other released her hold.

On 8 subseyuent occasions during November and December I saw homosexual behavior displayed by the lizards in this terrarium. Three 
different individuals at one time or another assumed the male role in abortive attempts to copulate. Whether this highly abnormal behavior on the part of a female lizard is brought on by intrinsic stimuli, extrinsic stimuli, or both is not evident. The fact that both mated and unmated individuals showed it obviously complicates the matter.

\section{Plghting}

Captive male skinks frequently fought during mating season. Certain males were particularly belligerent. One of these was a small ( 43 mn snout-vent length) individual collected at Fort Benning, Georgla, on September 10, 1960. This male, which was brightly suffused with orange-yellow on the lower sides, neck, and chin, exhibited sexual readiness to a marked degree. In the presence of a mature female he would at once begin to show courtship behavior.

On October 10, 1960, this skink was placed in a terrarium containing 4 laboratory-reared lizards, each in its first year. Two of these were the male offspring of a female from the Lake Wales Ridge of Polk County, Florida. Each was 46 in snout-vent length. Another was a $41 \mathrm{~mm}$ male from Levy County parents. All three males were sexually mature. I had never observed any aggressive tendencies among any of these Individuals. The fourth was a mature female, an offspring of the female from Polk County mentioned above.

After prowling about the terrarlum for a few seconds the Georgia male began vibrating his tall and yuivering slightly in sexual excitement. The female at this time was completely hidden from view. Continuing his exploration of the terrariur, he either avoided or paid little attention to the two Polk County males, which, together with the 
Levy County male, were foraging on the surface. However, upon every encounter with the Levy County male, he would attack and bite hlm savagely. If the smaller skink happened to be moving, the Georgia male would advance quickly and bite him on the tall, usually at a spot just to the rear of the vent.

The younger lizard responded by thrashing violently for a moment and, upon jerking loose from the jaws of his adversary, moving rapidly to the opposite end of the terrarium, where he nervously twitched and waved his tail. If, upon being confranted by his tormentor, the smaller skink remained quiet, the attack was more ceremonial. The Georgia 11zard would approach to within 2 or $3 \mathrm{~cm}$, turn his side toward the other, and move up close in jerky, sidewise fashion. After momentarily nudging him with his snout, he would bite the smaller one, usually about the basal portion of the tail.

After being harassed in this manner for about 15 minutes, the Levy County male burrowed into the sand, whereupon the Georgia lizard was removed from the terrarium. On the following day the Levy County male was dead. I suspect that this individual may have been diseased or in an otherwise weakened condition from the beginning.

The Georgia male was involved in numerous other fights, particularly with a first-year, sexually mature male which had been collected August 1, 1960, near Winter Haven, Polk County, Florida. This lizard, approximately the same size as the Georgla male, lived in a terrarium with 3 immature Individuals of Georgia parentage and 3 laboratory-reared young adults ( 2 males and 1 female), the offspring of a Levy County female. I had never noted any aggressive behavior between any of the 
residents of this terrarium. On several occasions I introduced the Georgia male into this terrarium. In nearly every instance a fight ensued almost immediately between him and the Polk County male. The two appeared to be almost equally matched, and the fights often lasted as long as 25 minutes. Usually, the Polk County male would terminate the battle by retreating from the scene.

These fights were, like courtship and mating in this species, characterized by ritualism. The combatants would sidle up to one another, jerking and quivering, with their bodies bent ridiculously in S-shaped curves, and their heads directed downward (Fig. 8A). Suddenly one would selze the other. The latter would imediately attempt to reciprocate, and, if successfully, there ensued violent thrashing, with each Individual rapidly twisting his body over and over. This lasted only a second or so and normally resulted in each skink gaining his freedom from the other's hold. This was followed by a resumption of the activity described.

Most frequently the skinks bit one another about the head and basal half of the tall. When a "head-hold" was secured by either individual, the other was obviously at a disadvantage, being unable to grasp his adversary (Fig. 8B). A lizard caught this way would usually crawl about for a few seconds and suddenly free himself by simultaneously jerking and twisting. Other fights were noted from time to time between various males but were usually one-sided and of falrly short duration. While observing these fights, I frequently got the distinct impression that the aggressor was endeavoring to break off the tall of the other lizard. A majority of the large (over $47 \mathrm{~mm}$ in length) male 
FIG. 8. Aggressive behavior in male Eumeces egregius. A. Two males just prior to fighting. Both are displaying the "aggressive attitude," in which the body is bent into an S-shaped curve, and the snout is pointed downward. B. One male has been seized by the head and is thus prevented from grasping the other. In thia predicament he will crawl forward very slowly for a few seconds, then free himself by violently jerking and twisting. 


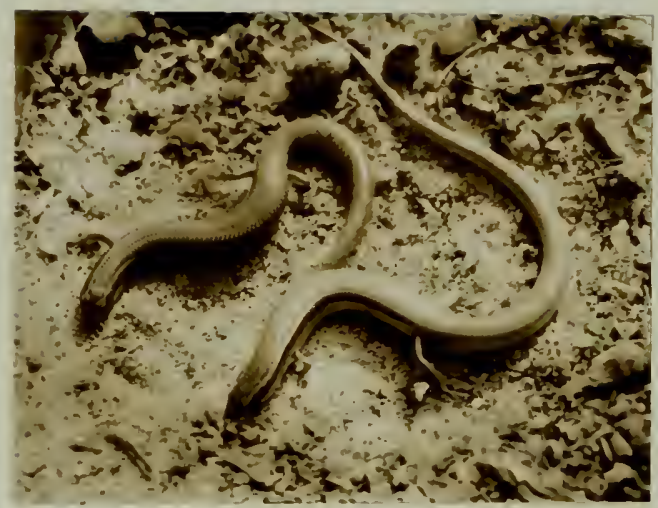

A

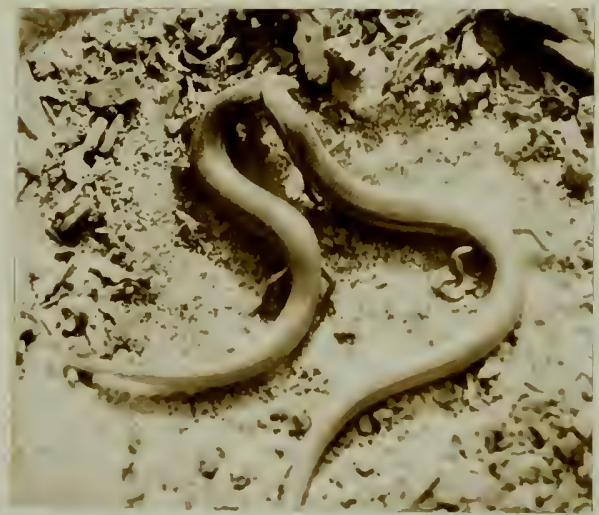


skinks collected from any given population were marked with scars, most of which can probably be attributed to fighting.

Captive female lizards showed no aggressive behavior of any kind except when they were brooding. Judging from some of the scars found on wild-caught individuals, however, I suspect that they do occasionally fight under natural conditions.

\section{Preoviposition Period}

The period between mating and oviposition in $\underline{\mathbb{E}}$. egregius is unusually long for a skink. The longest such perlod observed was 146 days. The female in question mated on November 17, 1959, was 1solated immedlately, and laid five fertile eggs on April 12, 1960. In the 1959-60 season all mature females collected after December had apparently mated. All those kept in captivity laid fertile eggs during the spring. Prolonged preoviposition periods, involving sperm-storage or delayed fertilization, have been reported in a number of snakes and in turtles, but not, as far as I know, in lizards.

Following 1 or 2 matings the females enter a phase of relative inactivity, which I call postmating quiescence. In the laboratory, females were seldom seen on the surface for 3 to 4 weeks after mating, and during this period they fed sparingly or not at all. In the study Area postmating quiescence was Indicated by the relative infrequency with which females were collected from Geomys and beetle mounds during and shortly after the mating season (Fig. 9). Also, a relatively large number of the females collected during this time had no food in their guts (Fig. 10). 


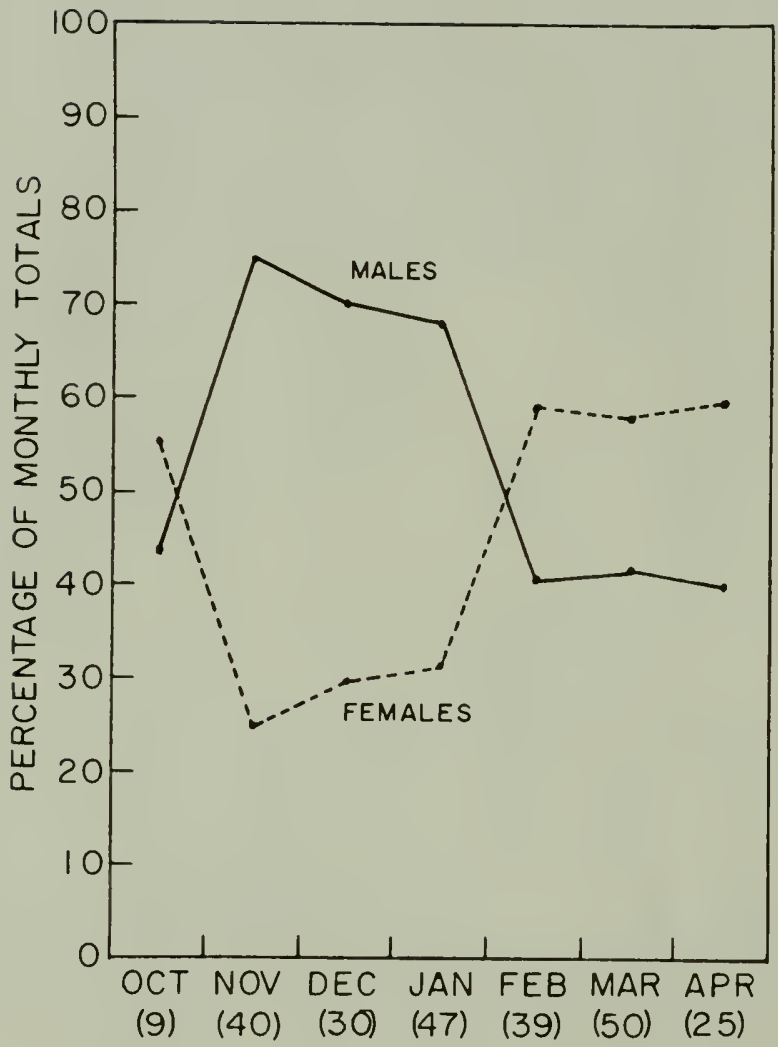

FIG. 9. Seasonal variation in relative frequency of capture of male and female Eumeces egreglus (Study Area, Levy County, Florida). Total numbers captured during each of the months is show in parentheses. Nearly all of these lizards were captured in Geomys or beetle mounds . 


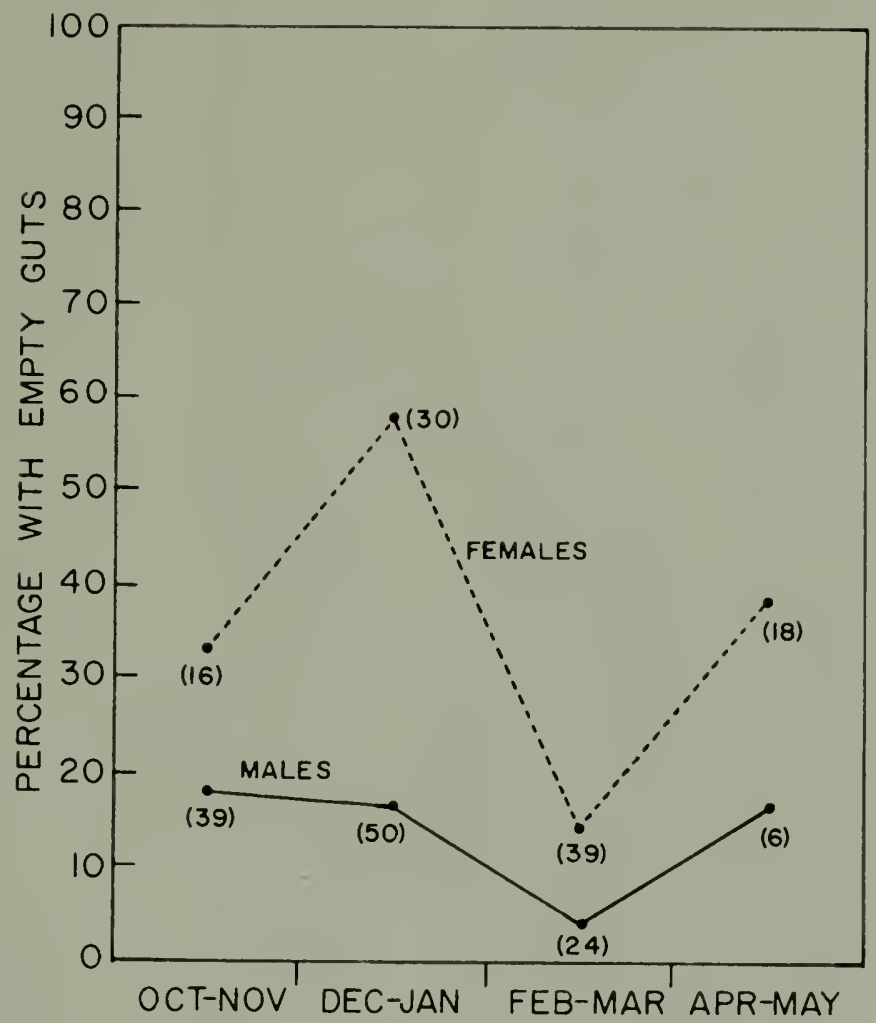

RIG. 10. Seasonal and sexual variation in feeding habits of Eumeces egregius, as indicated by proportions of individuals having empty guts (Study Area, Levy County, florida). The total number of each sex captured during the period indicated 13 shown in parentheses. During December and January many females had entered the phase of postmating quiescence (see text). During February and March most females were feeding actively and developing fat stores. During April and May the abdominal cavities of many females were almost curapletely filled with eggs, and the guts of such lizards were usually empty. 
Female postmating quiescence probably results in an increase in the efficiency of courtship and mating activity in this species. The rutting males would be less likely to detect and court the inactive and previously mated females, and, accordingly, superfluous sexual activity would be lessened.

During Eebruary and March female lizards were collected in the Study Area with much greater regularity than earlier, and the guts of only a few of these were empty. Apparently, this period is one of intensive foraging on the parts of the females. Their tails become heavy with atored food. In March and April their bodies become noticeably distended with eggs. As the eggs occupy more and more of the body cavity, the digestive tract gradually becomes so crowded that digestion and elimination are apparently hindered. This would account for the increase noted in percentage of females with empty guts during April and May.

In Fig. 11, the diameter of the largest ovarian follicle or oviducal egg is plotted against the date of preservation for each female collected from the Study Area and preserved during 1959-60. Small (under $0.5 \mathrm{~mm}$ ), nearly translucent follicles were present in obviously immature specimens. The advent of sexual maturity was marked by a rather abrupt increase in the sizes of the follicles which at the aame time became opaque and creamy or yellowish in color. After this initial enlargement the folicles showed little change in size until February, when secondary follicular enlargement began in some females. By late March most females contained enlarged follicles. Size increase continued through March, and ovulation began in April. 


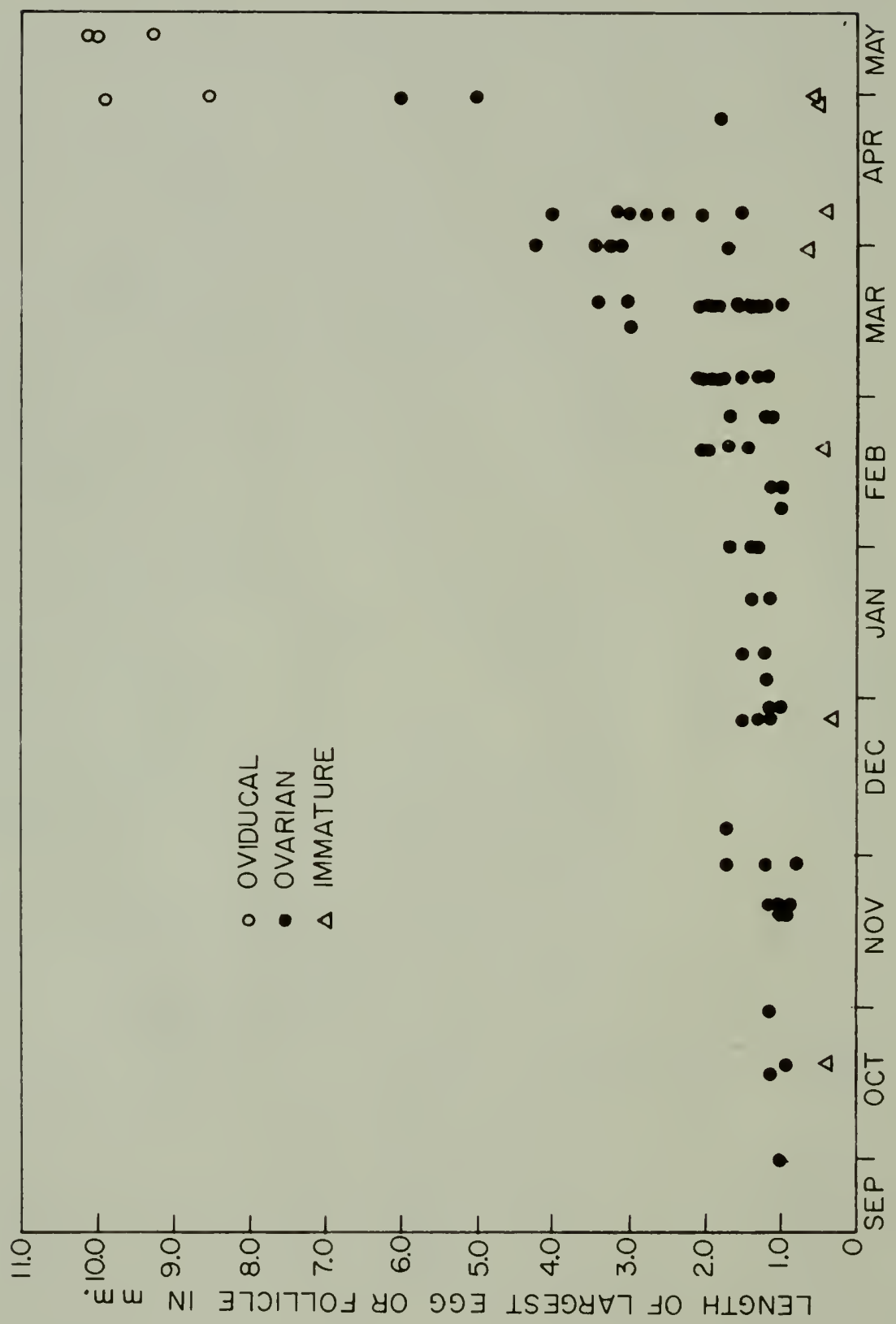




\section{Nests}

In a paper presented at the $37 \mathrm{th}$ annual meeting of the American Society of Ichthyologists and Herpetologists in 1957, Wilfred T. Neill

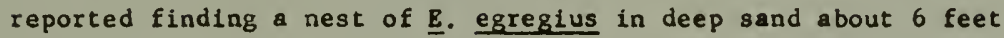
beneath the surface. Hamilton and Pollack (1958) report that on June 15, 1950, a nest of this species was uncovered at a depth of 4 inches in sandy soll at Ft. Benning, Georgia. These are the only published references to natural nests of the red-tailed skink.

No natural nests were found during the present lavestigation, but I observed nesting activity among captive specimens on a number of occastons during 1960 and 1961. Between April 3 and June 15, 1960, 14 captive females nested (Table 3). Gravid females were individually confined in wide-mouthed, gallon-sized glass jars containing about $8 \mathrm{~cm}$ of slightly moistened sand. In nearly every instance the female constructed her nest cavity against the bottom of the jar. The nests were ordinarily clearly visible from beneath. The cavities were more or less rounded and measured from 4 to $8 \mathrm{~cm}$ across and about $2 \mathrm{~cm}$ in depth. Each nest was completely enclosed and had no passageway to the surface.

Although these jars were examined almost daily, and nests were observed in all stages of construction, only once was a lizard seen actually hollowing out a cavity. She was crawling around slowly, pushing back the sand with the sides of her head and neck. She stopped after a minute or so, apparently having been disturbed by my presence. Several days elapsed between the apparent completion of any nest and 
TABLE 3. Size of female parent, number of eggs per clutch, and dates of oviposition and hatching for 14 clutches of eggs of Eumeces egregius (1960).

\begin{tabular}{|c|c|c|c|c|}
\hline $\begin{array}{l}\text { Snout-vent } \\
\text { length of } \\
\text { female }(\mathrm{mm})\end{array}$ & $\begin{array}{l}\text { Number } \\
\text { of eggs } \\
\text { in clutch }\end{array}$ & $\begin{array}{c}\text { Date of } \\
\text { oviposition }\end{array}$ & $\begin{array}{l}\text { Date of } \\
\text { hatching }\end{array}$ & $\begin{array}{c}\text { Number of days } \\
\text { between oviposition } \\
\text { and hatching }\end{array}$ \\
\hline 46 & 4 & Apr11 3 & May 20 & 48 \\
\hline 55 & 6 & April 4 & May 24 & 51 \\
\hline 58 & $?$ & April 7 & May 20 & 44 \\
\hline 42 & 6 & April 12 & May 21 & $39^{a}$ \\
\hline 50 & 9 & April 18 & June 5 & 49 \\
\hline 50 & 5 & April 21 & June 3 & 44 \\
\hline 49 & 5 & May 8 & June $14-15$ & $38-39$ \\
\hline 42 & 4 & May 13 & June $17-18$ & $36-37$ \\
\hline 52 & 5 & May 14 & June $21-22$ & $39-40$ \\
\hline 50 & 5 & May 20 & June $24-25$ & $36-37$ \\
\hline 47 & 2 & May 23 & June 29 & 38 \\
\hline 47 & 3 & May 25 & July 1 & 38 \\
\hline 46 & 4 & May 29 & July 3 & 36 \\
\hline 59 & 5 & June 13 & July $13-14$ & $31-32$ \\
\hline
\end{tabular}

ahis clutch was taken from female and held in jar with moistened newsprint until time of hatching. 
the appearance of the first eggs. The shortest such pertod was 3 days, and the longest, 10 .

\section{Oviposition and Eggs}

Since I never actually saw the laying of the first egg of any clutch, I was unable to determine the exact amount of time reyuired for a given individual to complete oviposition. For clutches of 4 to 6 eggs, this time ranged from approximately 6 to almost 24 hours. The average period was probably 12 to 15 hours.

For 13 clutches laid in the laboratory the number of eggs per clutch averaged 4.8, ranging from 2 to 9 (Table 3 ). Hamilton and Pollack (1958) reported 2 clutches of five eggs each.

The eggs are described by Hamilton and Pollack (1958) as elliptical and dull white when laid, with some showing a faint yellowish tint. Table 4 summarizes measurements made on 4 clutches of freshly laid eggs. Mean length and mean width of the eggs in each of 3 Florida clutches are significantly greater ( 5 per cent level) than correspondIng means for a Georgia clutch.

The shells of the eggs are leathery and thin. One egg broke when accidentally dropped on a wooden floor from a height of about $27 \mathrm{~cm}$. About 1 week before the eggs hatch, their shells develop translucent areas, through which the fetuses are plainly visible.

The eggs become larger as development proceeds. The eggs in a clutch laid by a female from Highlands County, Florida, showed an average increase of $4.0 \mathrm{~mm}$ in length and $3.0 \mathrm{~m}$ in width from the time they were laid until just before hatching. Corresponding figures for a 
clutch laid by a Georgia female are given by Hamilton and Pollack (1958) as $3.8 \mathrm{~mm}$ and $1.1 \mathrm{~mm}$.

TABLE 4. Measurements of freshly laid eggs of Eumeces egregius in millimeters.

\begin{tabular}{|c|c|c|c|c|c|}
\hline Female collected at: & $\begin{array}{l}\text { No. eggs } \\
\text { in clutch }\end{array}$ & $\begin{array}{l}\text { Range in } \\
\text { length }\end{array}$ & $\begin{array}{l}\text { Mean } \\
\text { length }\end{array}$ & $\begin{array}{c}\text { Range in } \\
\text { width }\end{array}$ & $\begin{array}{l}\text { Mean } \\
\text { width }\end{array}$ \\
\hline Ft. Benning, $\mathrm{Ga}^{\mathbf{a}}$ & 5 & $8.5-9.0$ & 8.9 & $5.0-5.5$ & 5.2 \\
\hline $\begin{array}{c}\text { Levy County, Fla. } \\
\text { (Study Area) }\end{array}$ & 5 & $9.6-10.5$ & 10.0 & $5.9-6.6$ & 6.3 \\
\hline $\begin{array}{l}\text { Levy County, Fla. } \\
\text { (Study Area) }\end{array}$ & 4 & $10.1-11.0$ & 10.4 & $6.0-6.6$ & 6.3 \\
\hline $\begin{array}{l}\text { Highlands Co., Fla. } \\
\text { (Lake Wales Ridge) }\end{array}$ & 6 & $10.1-11.6$ & 10.6 & $6.0-6.7$ & 6.5 \\
\hline
\end{tabular}

\section{Data on this clutch taken from Hamilton and Pollack (1958).}

The incubation period varied from 51 days for a clutch laid on April 4 to 25 days for one laid on June 13. Temperature was apparently the most important factor in determining the length of the period.

\section{Brooding}

Brooding behavior among members of the genus Eumeces has been studied and discussed by several workers, including Noble and Mason (1933), Fitch (1954), and Evans (1959). The activities of the brooding females of the various species are probably similar in most respects. Generally, they appear to consist of cleaning and turning the eggs, protecting them from certain forms of predation, and minimizing the effects of desiccation by vertically shifting the position of the nest, 
and, at least in E. fasclatus, by volding the contents of the bladder when the need arises. In $\underline{E}$. obsoletus the female assists in the hatching process and attends the young for several days after batching.

The brooding instinct appears to be highly developed in E. egregius. In fact, brooding females I observed normally remained in their nest cavities constantly, neither feeding nor drinking, from the time the nests were made until the young had hatched and dispersed. The longest such time was 56 days.

The brooding lizards frequently turned their eggs and cleaned them whth their tongues. Cleaning may be essential for proper development, particularly in the early stages. On several occasions I removed eggs from nests and attempted to hatch them in the absence of the females. These eggs were kept in closed jars containing moistened newsprint and were turned dally. Eggs cared for by the female for several days before removal usually developed normally; freshly lald eggs (less than one day old) so used were invarlably attacked by fungus. Perhaps freshly laid eggs are coated with a film conducive to mold growth, and this is removed early by the female's licking.

Occaslonal turning of the eggs appears to be important to development. The following observations may be significant. One large female ( $58 \mathrm{~mm}$ snout-vent length) constructed a nest cavity in which she laid six eggs. Twelve days after laying she was discovered on the surface in a weakened condition. She refused both food and water and died two days afterward. All of her eggs had spolled, but not, apparently, from molding. It seemed that they had been pald little attention, and each 
had yellowed on one side and become slightly shrunken. They may hava spoiled from not having been turned.

Brooding females probably protect their nests from certain forms of predation. Once I made a slight opening into a nest cavicy occupled by a female brooding over one egg. While observing through the bottom of the jar, I allowed a 20-cm Tantilla coronata to put its head through the opening and into the nest. The lizard nosed the intruder for a moment, then bit him savagely. The snake withdrew its head immediately. Next, I introduced the head of a $38-\mathrm{cm}$ Thamnophis sirtalis into the cavity. The lizard watched the snake's head attentively and showed no signs of alarm. When it moved closer, she backed against the far side of the cavity but still made no attempt to desert. I then withdrew the snake, walted for a minute or so, then eased his head into the cavity again. This time the 11 zard bit the snake on the lip and Imediately backed away. I thrust the snake's head farther into the cavity, but the lizard did little but make mild attempts to avoid it. It seems certain such actions on the part of a brooding female lizard might discourage small predators.

On five occasions I removed eggs from nests to take measurements. The females made no attempts to defend their nests against my intruslons and did not desert them until the eggs were completely exposed. Only one female resumed brooding the eggs after they had been removed, measured, and replaced. In this case I had removed the eggs on the day following oviposition and had destroyed the nest cavity in the process. After messuring the eggs, I placed them together on the surface of the sand in the original nest jar. Twelve hours later they had not been 
moved, and the lizard was lyling under the sand next to the bottom of the Jar. I then hollowed out a small cavity about $6 \mathrm{~mm}$ in front of the tip of her snout, placed the eggs in this cavity, and covered it with a flat piece of bark. Six hours later, she was in the cavity coiled about the eggs, where she remained for the rest of the incubation period.

I could not deterwine if the females assist in the hatching process. At hatching time they moved nervously about, touching the emerging and newly emerged young with their tongues. I did not observe a female actually helping a hatchling to emerge from the shell. After the young dispersed from their nests, their mothers paid them little attention. By this time the mother skinks were noticeably emaciated. Their tails, which had earlier been heavy and well rounded, were now shrunken. They began feeding immediately, however, and within a month or so were normal in appearance.

Noble and Mason (1933) suggested that the incubation period for eggs of Eumeces fasclatus may be shortened as a result of heat transfer from the body of the brooding female. Pitch's observations (1954) failed to confirm this view. Evans (1959) found no evidence for this phenomenon in Eumeces obsoletus. I took numerous E. egregius nest temperatures to within $0.2^{\circ}$, and in no case were they different from those of the surrounding soll.

\section{Hatching and the Hatchlings}

Hatching in Eumeces egregius was briefly described by Hamilton and Pollack (1958). The following is based on their description and my 
own observations. About 2 days prior to hatching, the fetus can be seen moving about within the egg. Moisture oozes from the egg and forms small droplets externally. The appearance of this molsture may coincide with breakage of one or more of the extraembryonic membranes. The shell is punctured by a sudden thrust of the snout, directed forward and upward against the inner surface of the shell. A slit about $4 \operatorname{man}$ long appears, through which the head protrudes. The slit is presumably made with the aid of the egg tooth, which is lost during the first or second day.

After the initlal break-through, the young skink may remain in the egg, with only its head protruding, for 4 hours or more. I never saw a hatchling emerge in less than 2 hours. The lizard moves but little during this period, and, if molested, is likely to draw lits head back into the egg.

After emerging, the hatchlings spend the first 4 or 5 hours lying quietly and breathing deeply once every 3 to 6 seconds. A bit of the yolk sac protrudes from the umbilicus of each. By the end of the first 24 hours, they are fairly active and are usually beginning to moult. By the end of the second day, the umbilici heal and moulting is complete, or nearly so.

Dispersal fron the nest ordinarily takes place during the third day. The hatchlings are lively and feed readily on termites and small roaches. While foraging, they keep their tails almost constantly in motion. The basal half moves from side to side, while the remainder wriggles in sinuous curves. This trait is also seen in the hatchlings of E. obsoletus (Grant, 1927), and in the hatchlings and juventles of 
Eumeces sk1ltonianus (Tanner, 1957) and E. fasclatus (F1tch, 1954). Hatchling $\underline{\mathbb{E}}$. obsoletus and $\underline{\mathbf{E}}$. fasclatus show a tendency to arch the tall vertically; I noted no such tendency 10 E. egreglus hatchlings.

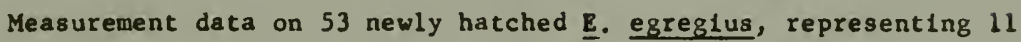
clutches, are summarized in Table 5. Generally, the largest hatchlings were those of Lake Wales Rldge parentage. There were no sexual differences in size or external appearance of hatchlings.

Sex was determined for 31 laboratory-hatched akinks; 11 were males and 20 , females. While this difference is not algnificant at the 5 per cent level, it demands a more thorough investigation of this aspect of the life history.

As In the case of most lizards, the hatchlings of E. egreglus differ in appearance from the adults in several respects. The ground color of the hatchling is darker, and the pattern of atriping, while basically similar to the parental pattern, is usually more distinct. The head is relatively larger in the hatchling, and the tail, which is more vivid in color, 18 proportionately shorter.

\section{Growth and Development}

I studied growth and development of 12 sets of siblings hatched In the laboratory, and at varlous time Intervals measured the individuals in 6 of these. Two of these 6 were from eggs laid by females taken from the Lake Wales RIdge in Highlands County, Florida, and 1 each from females collected in Levy County, Florida; Putnam County, Florida; Marion County, Georg1a; and Autauga County, Alabama. Al1 these females had mated prior to being collected. The growth data are condensed in Table 6 and Fig. 12 . 


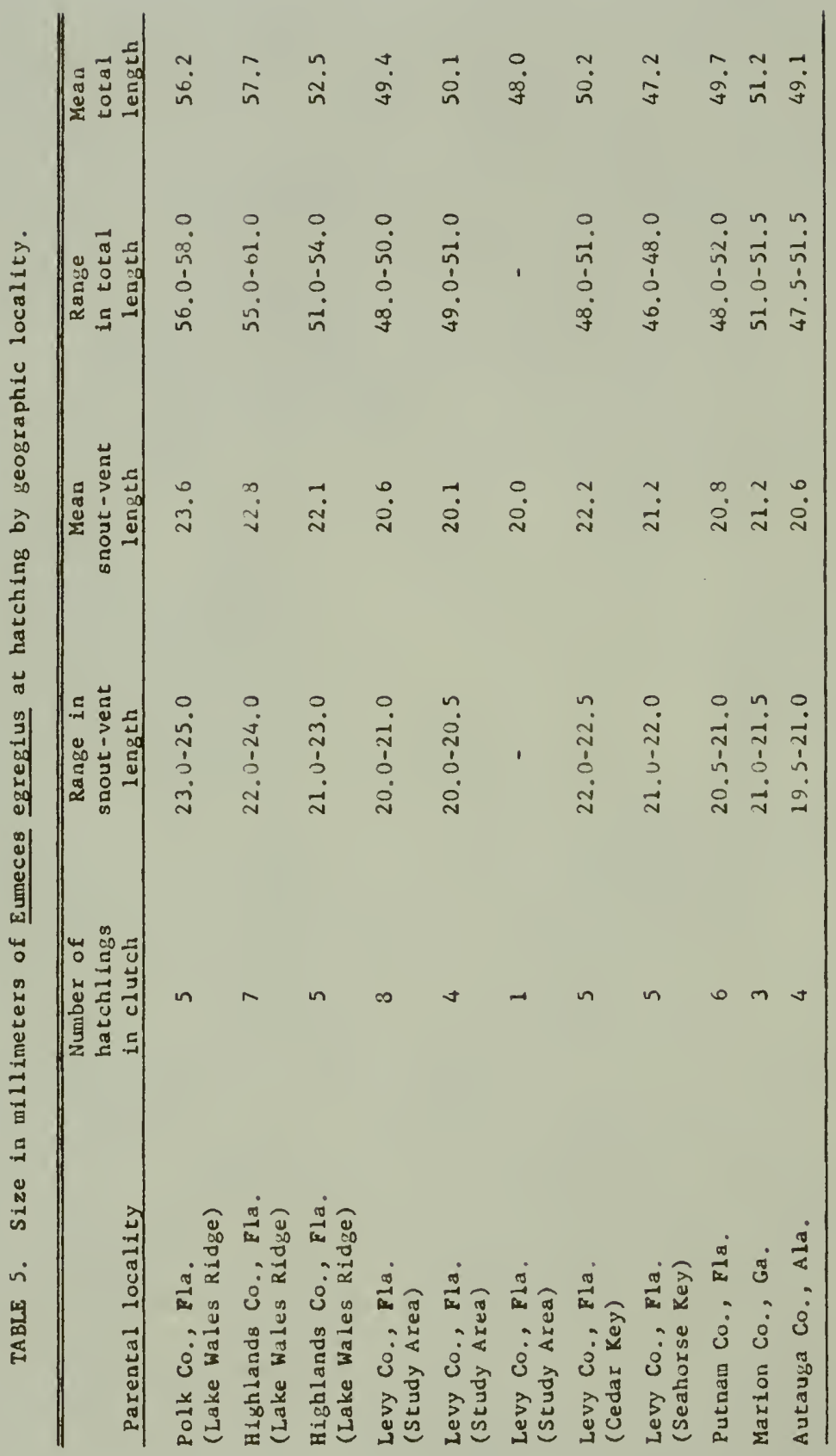




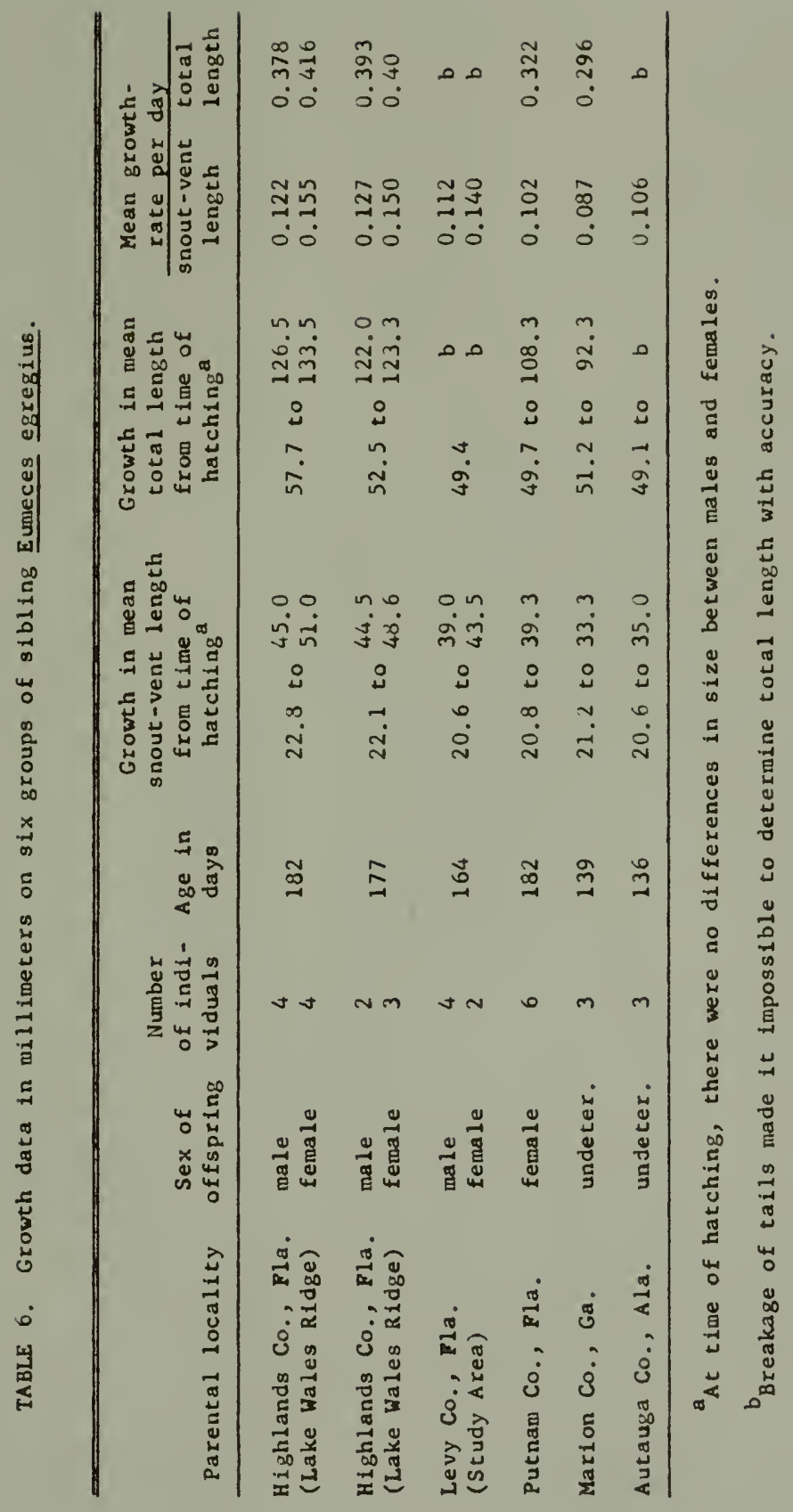


FIG. 12. Average increase in snout-vent length from time of hatching for six groups of sibling Eumeces egreglus reared in the laboratory. Numbers of individuals in each group or sub-group are shown in parentheses. Offspring of southern parentage grew faster than those of northern parentage. Differences in growth rate between males and females are shown for some groups. 


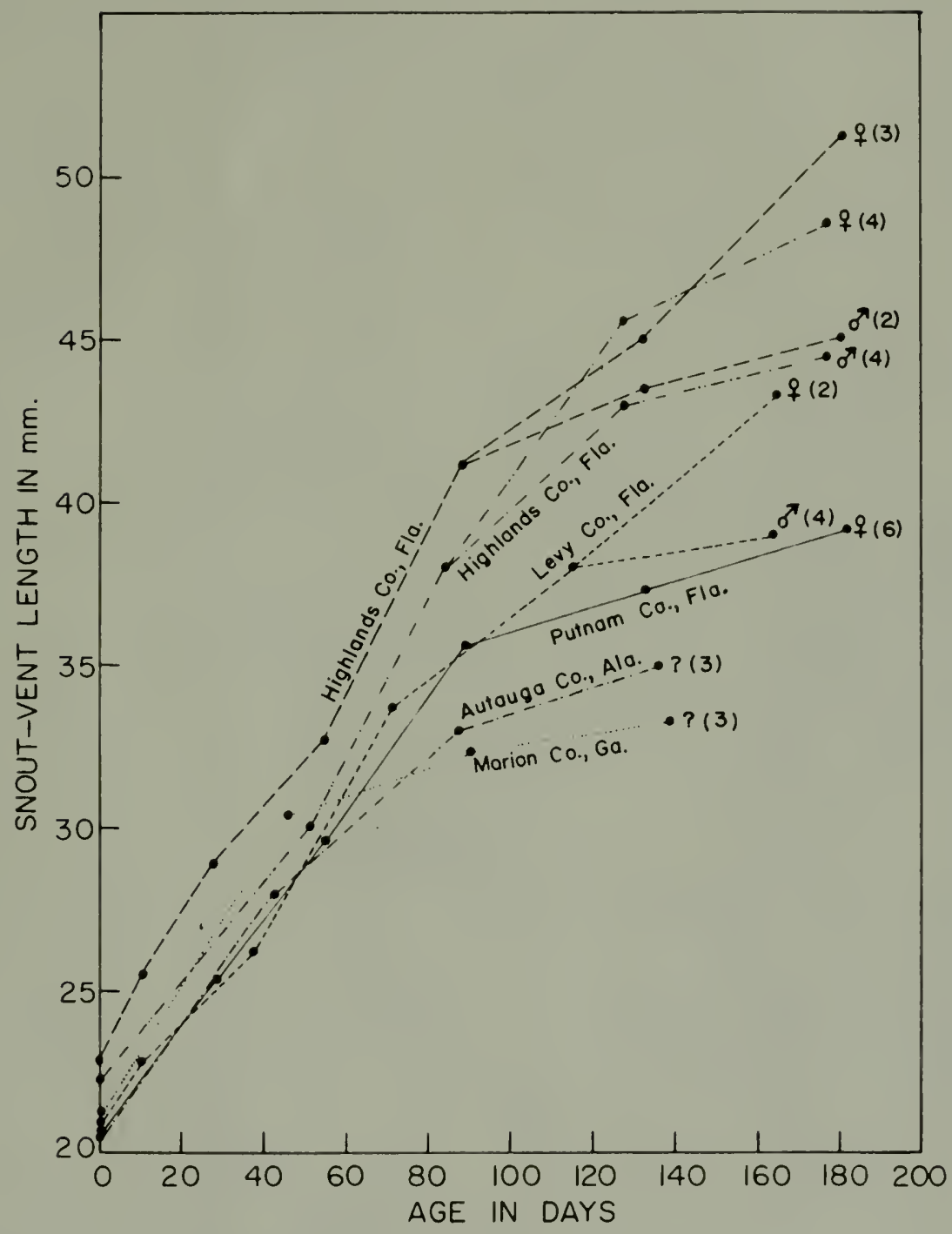


Marked differences in growth and development were noted among some sets of siblings. Skinks in the 2 Highlands County sets showed the most rapid growth rates. In 1 of these each of the 5 individuals had grown to at least twice its original size in snout-vent length in 128 days. A similarly rapid rate of relative growth has been shown for E. fasclatus during the summer months after hatching (Fitch, 1954). The western blue-tailed skink (Eumeces skiltonianus), however, requires a full year to double its original size (Rodgers and Memmler, 1943).

The Georgia and Alabama red-tailed skinks grew much more slowly. The Georgla siblings showed an average increase in snout-vent length of 58.6 per cent at 139 days of age, and those from the Alabama parents, 70.0 per cent at 136 days. The lizards in the other two Florida sets were intermediate in growth rate. I was unable to get data on growth rates of the Plorida Keys red-tailed skinks. Growth rates might be of value in establishing the intraspecific relationships of these lizards. In morphology the Key lizards appear to be more closely related to those of northern Plorida, Georgia, and Alabama than to the ones in central and southern Plorida (McConkey, 1957).

In all sets in which comparison could be made, females grew faster than males. The ages between which the sexual differences in growth rate appeared for each of the Florida sets can be seen In Fig. 12. The greatest difference noted was in a Highlands County set in which the females averaged 13.3 per cent larger than the males at 182 days of age. I was unable to make positive sex determinations on the 
Georgia and Alabama siblings. In neither of these sets, however, were there differences in size of over $4 \mathrm{tmm}$.

Under laboratory conditions females over 50 snout-vent length and males over $45 \mathrm{~mm}$ grew slowly. In elght months of captivity one female from Highlands County grew from 56 to $59 \mathrm{~mm}$, and another, during this time, grew from 52 to $54 \mathrm{~mm}$. A female from Georgla, $51 \mathrm{~mm}$ in length at time of capture, grew only $1 \mathrm{~mm}$ in $\mathrm{s} 1 \mathrm{x}$ months. A male from the Study Area increased in $81 z e$ from 44 to $46 \mathrm{~mm}$ in $81 x$ months. A Georgia male required ten months to grow from a size of $44 \mathrm{~mm}$ to one of $46 \mathrm{~mm}$.

The largest Individuals, both in maximun size and in mean adult size, were found on the Lake Wales Ridge and on Cedar Rey Airstrip Island and Seahorse Key (Fig. 13). Those from Georgla, Alabama, and northern Florida, designated Eumeces egregius similis by McConkey (1956), were smaller by from 4 to $6 \mathrm{~mm}$. Intermedlacy in this character was noted for the other populations sampled. In every population studied the largest females were 3 to $7 \mathrm{~mm}$ larger than the largest males. The largest specimen examined was a female 62 m in snout-vent length from the Lake Wales Ridge in Polk County. This specimen shrunk to $59 \mathrm{~mm}$ after $\mathbf{s} 1 \mathrm{x}$ months in preservative. In the preserved collec$t$ ion of $S$. R. Telford, $J r$, is a female specimen (SRT-640h) from Cedar Key Airstrip Island measuring $60 \mathrm{~mm}$. The size of this individual in 11 fe probably exceeded that of the Polk County female and might be designated as the record for size for the species. The largest male, collected on the Lake Wales Ridge in Polk County, was 56 at time of preservation and $\mathrm{six}$ months later measured $53 \mathrm{~mm}$. 


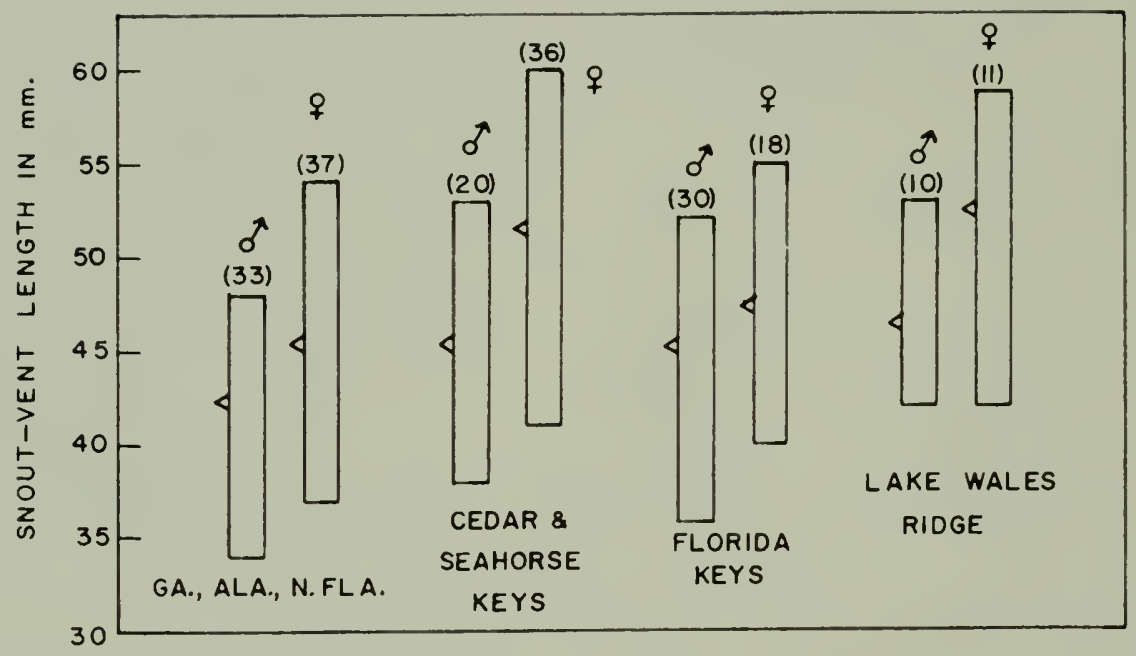

FIG. 13. Geographic and sexual variation in size of adult Eumeces egregius. The size of each sample is shown in parentheses. Pemales were larger than males in every population studied. The northern Florida area is north of Levy, Alachua, Clay, and St. Johns Counties. 
Size could not be used to classify specimens according to age groups. This is understandable when one considers the relatively long season over which hatchlings are produced in most parts of the range, In Florida a period which may last three to four months. I can offer no evidence as to the physiological longevity of red-talled skinks.

Sexual maturity is reached in the first or second year. On the Lake Wales Ridge all the Individuals apparently reach sexual maturity and mate during the first fall or winter after hatching. Males reared from eggs la1d by females collected from that area began to show the orange suffusion of sexual maturity at 124 days of age. Both males and females in one set of Lake Wales Ridge siblings were mating at 130 days of age. Mating was observed among the siblings of two other Lake Wales Ridge sets when they were, respectively, 144 and 148 days old. I collected on the Lake Wales Ridge only in January and February, and it seems significant that no immature individuals were among the 20 or so specimens I was able to capture there.

In the north-central portion of Florida, some individuals reach maturity during the first year, while others do not. In each of two sets of siblings from Study Area parents, both males and females were apparently sexually mature by October 14. At that time one of these groups was 125 days old and other 135 days. Siblings from Putnam County and those from Cedar Key Alrstrip Island and Seahorse Rey parents matured during the first fall. However, field collecting in northcentral Florida revealed the presence of immature lizards in many of the populations as late as March and April. It is unlikely that these would mate before the following fall. 
None of the siblings among the Georgia and Alabama sets matured during the first fall. These individuals were still frature at almost 1 year of age. This, along with observations made in the field, lead me to conclude that a relatively slow rate of growth and development ia characteristic of the Fall Line Hills populations of E. egregius, and that, probably, none of the individuels reach maturity before 1 year of age. Other populations worthy of investigation in this regard are those inhabiting the southern portions of Georgla and Alabama, extreme northern and northwestern Plorida, the lower eastern and western coasts of Florida, and the Florida Keys.

The size at which sexual maturity is reached varies between 34 and $38 \mathrm{~mm}$ snout-vent length for males and between 36 and 42 mo for females. There appear to be geographic differences in this characteristic, with the lizards of the more northerly distributed populations maturing at slightly smaller sizes than the ones of those to the south. More data are needed to establish this.

\section{Postnesting Activity}

There was nothing unusual about the postnesting activities of captive skinks. Both hatchlings and adult females spent considerable time foraging; adult males were somewhat less active. During the study period I was unable to collect red-tailed skinks in either Geomys or beetle mounds from wid-May to mid-September (see page 16). I collected a few specimens during this time, however, by digging under tidal wrack on Cedar Key Airstrip Island and Seahorse Key, by overturning rocks at Key West and Stock Island, and by digging under fallen palmetto frunds in a scrub in Polk County, Florida. 
Hamilton and Pollack (1956) found red-tailed skinks in the stomachs of the coachwhip (Masticophis flagellum), blacksnake (Coluber constric-

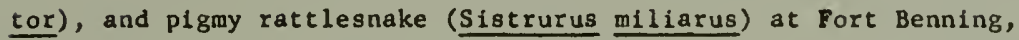
Georgia. I know of no other literature records concerning predation on $\underline{B}$. egreglus. Only one instance involving natural predation was noted during the present Investigation. On March 14, 1960, a freshly ingested tail of one of these skinks was recovered from the stomach of a $30-\mathrm{cm}$ Lampropeltis doliata collected in a Geomys mound in the Study Area. This snake often shows semi-fossorial tendencles and eats $11 z-$ ards. I suspect that it frequently preys upon red-tailed skinks where It occurs sympatrically with the latter. Other snakes known to feed on small reptiles or their eggs and are often members of the same ecological communities as red-tailed skinks include the short-tailed snake (Stilosoma extenuatum), eastern indigo snake (Drymarchon corais couperi), scarlet snake (Cemophora coccinea), and coral snake (Micrurus fulvius fulvius).

Important mamalian predators are perhaps the striped skunk (Mephitis mephit1s), the spotted skunk (Spilogale putorium), and the nine-banded armadillo (Dasypeltis novemclnctus), which are omnivorous and spend considerable time rooting about in sandy soll. Birds are probably of little importance as predators upon this species. 
One hundred twenty-five red-tailed skinks collected in the Study Area had clearly lost their original talls; 72 had not. I was uncertain about the tails of 64 others. More large skinks had lost their talls than small ones. There was no difference between sexes in this regard. I have no way of knowing how many of the tail losses could be attributed to predators, and how many may have resulted from fighting and courting. I think it is only logical to assume that many, if indeed not most, were lost to predators, and that the tail is of great importance in enabling a skink to survive a predatory attack. Behavioral traits which would tend to enhance the effectiveness of the tall in this role have been discussed in previous sections.

The red-tailed skinks collected had few ectoparasites. Trombicu$11 d$ mites were the only ones noted and were found on but 4 of the 425 specimens examined. Most of these lizards were taken during the cool months of the year, however, and one might perhaps expect the infestations to be higher during the sumer.

Nematodes occurred in the stomachs of 15 specimens, and cestodes in 2. These parasites have been submitted to an authority for identification. No efforts were made to find protozoan symbionts. 


\section{POPULATION DYNAMICS}

\section{Dispersion and Structure}

Red-tailed skinks tend to be gregarious. Bven in extensive areas of seeningly ideal habitat, it was often necessary to hunt for an hour or so before locating a skink, but almost invariably when one was encountered, one or more others were found nearby. Some of this grouping may have been the result of independent reaction to the same favorable features of the locality. In areas of rolling topography, for Instance, the sumbits of hills and knolls were almost always more productive as collecting sites than low-lying areas. It is possible that moisture conditions were more favorable at such sites. There was no evidence of territorlallty among the males. On 4 separate occasions during the height of the mating season, 2 mature males were found occupying the same Geomys mound.

Some statements regarding population structure have al ready been made (see section entitled Growth and Development). In view of the selective nature of the collecting methods used in this study and the marked geographic variation in growth and development in this species, it seems futile to pursue the matter at greater length.

\section{Density and Movements}

The greatest density observed was on a hilltop in the Study Area 4 miles southwest of Archer. Here vegetation consisted of a sparse growth of turkey oak, an occasional rosemary bush, and scattered clumps 
of wiregrass. Approximately 60 per cent of the ground surface was exposed. About 35 Geomys mounds were distributed more or less at random over an area of 50 by 70 yards, which included the summit of the hill. A total of 18 skinks, 11 females and 7 males, were found within this area between January 26 and March 24, 1960. All of these were sexually mature. Sixteen were found in Geomys mounds; the other 2 were found just beneath the surface under a plece of tin. Each lizard was marked by toe-clipping and released immediately. When an individual was taken from a Geomys mound, the mound was reshaped, and the lizard was released by allowing it to burrow into the mound.

Only 2 lizards were recaptured. Both were females and were found after approximately one month in Geomys mounds 7 meters and 9 meters, respectively, from the ones in which they had been taken originally.

If one assumes that the 18 individuals located in the area were residents, a density of almost 25 mature lizards per acre is indicated. Moreover, it is doubtful that all those inhabiting the area were caught, so the actual figure is probably higher.

The presence of pocket gophers, gopher turtles, and sand beetles probably does much to enhance the carrying capacity of the habitats in which they construct their burrows. These burrows provide homes and retreats for vertebrates such as Mephitis mephitis, the Florida deer mouse (Peromyscus floridanus), the gopher frog (Rana areolata), the diamondback rattlegnake (Crotalus adamanteus), Masticophis flagellum, and, probably, Eumeces egregius. In addition their presence would seem to result in a greater abundance of many invertebrates, which are eaten by larger animals and by their prey. Possibly there exists in sandhill 
and scrub associations a direct correlation between animal biomass and the extent to which the community has been provided with these underground passages. 


\section{SUMMARY AND CONCLUSIONS}

The red-tailed skink is a small, fossorial lizard occurring locally in Georgia, Alabama, and Florida. It is found almost exclusively in areas of well-drained, sandy solls, which in most parts of the range support sandhill and scrub vegetational associations. There are no records of its having been collected west of the Black Warrlor or Tombigbee Rivers, and there is but one record (Randolph County, Alabama) for an occurrence outside the Coastal Plain. Red-talled skinks were studied in the laboratory and in the field from September, 1959, to July, 1961, to obtain information on their behavior and ecology. In sandhill associations they were collected chiefly by raking through mounds of sand pushed up by Geomys pinetis and vartous geotrupine scarab beetles. In scrubs they were taken by digging under fallen palmetto fronds, decaying Spanish moss, and other ground litter. Certain insular populations were assoclated with the tidal wrack along the shorelines.

The preferred temperature range of the red-talled skink lies between $26^{\circ}$ and $34^{\circ}$. Thermoregulation is seemingly dependent upon the individuals' ability to move readily through the soll from one temperature stratum to another. The frequent occurrence of these skinks, as well as Neoseps reynoldsi and certaln other fossorial reptiles, in Geomys and bettle mounds can, I think, be attributed to attempts to increase their body temperatures; the interlors of the mounds can thus be regarded as "basking sites." 
Eumeces egregius moves through loose soll by lateral, undulatory, "swiming" movements. It is not, however, nearly as proficient as Neoseps in "sand-swiming." On the surface the short, relatively feeble legs aid in locomotion.

The food of this lizard consists of small arthropods, and the composition of the diet of a given group of Individuals appears to be more a matter of avallability than of preference. In scrub and sandhi11 associations, the lizards eat certain roaches, spiders, and crickets. It is suggested that they encounter most of their food while prowling about in burrows of other animals, probably those of Geomys pinetis in most cases. At Cedar Key Alrstrip Island and Seahorse Key, amphipods are the principal food items.

In most parts of the range courtship and mating occur chiefly during the fall and winter. Courtship is highly ritualistic, and in most instances the mating act is relatively prolonged, lasting from 15 to 30 minutes. In mating the male seizes the female on the side just behind a front leg and directs his body first over then under that of the female. During the mating season the males show bright yellow, orange, or reddish-orange suffusion about the sides, neck, and chin, and sometimes on the belly and throat. Males recognize females chiefly by odor. In captivity the males occasionally fight among themselves. Homosexual behavior was noted only among females.

After mating, the females become relatively inactive for 3 to 4 weeka. Following this quilescent period they feed voraciously and develop fat stores. Nesting activity is greatest from April through June. Nest cavities are hollowed out in the soll at depths ranging 
from several inches to 6 feet beneath the surface. From three to seven eggs are usually laid, and the female broods the clutch constantly from the time of laying until the young have hatched and dispersed. During this time she cleans and turns the eggs. These activities may be essential for proper development. The female is thought to protect the nest from certain forms of predation.

The rate of growth and development is highly variable. In the laboratory young lizards of Plorida parents grew rapidly and attained sexual maturity and mated during the first fall. Those of Georgia and Alabama parents grew more slowly and were st 111 imature at almost 1 year of age.

In all parts of the range females become larger than males. The largest specimen examined, allowing for shrinkage in preservation, is a female from Cedar Key Airstrip Island, and measures 60 mm snout-vent length.

Red-tailed skinks are probably gregarious. There is no evidence of territoriality among males. Known predators include Masticophis flagellum, S1strurus miliarus, Coluber constrictor, and Lampropeltis doliata. One per cent of the specimens were parasitized by trombiculid mites; 3.5 per cent by nematodes; and 0.5 per cent by cestodes. 


\section{LITERATURE CITED}

Babbitt, L. H. 1951. Courtship and mating of Eumeces egregius. Copeia, 1951: 79.

Bogert, C. M. 1949. Thermoregulation in reptiles, a factor in evolution. Evolution, 3: 195-211.

Breckenridge, W. J. 1943. The life hlstory of the black-banded skink Eumeces septentrlonalis septentrionalis (Baird). Amer. Midl. Nat. 29: $591-606$.

Carr, A. P. 1940. A contribution to the herpetology of Florida. Univ. Plorida Publ. B1ol. Sci. Ser. 3: 1-118.

Duellman, W. E. and A. Schwartz. 1958. Amphibians and reptiles of southern Florida. Bull. Florida State Mus. 3: 181-324.

Evans, L. T. 1959. A motion picture study of maternal behavior of the lizard, Eumeces obsoletus Baird and Girard. Copeia, 1959: 103-110.

Fitch, L. T. 1954. Life history and ecology of the five-lined skink, Eumeces fasciatus. Univ. Kansas Publ. Mus. Nat. Hist. 8: 1-156.

- 1956. Temperature responses in free-11ving amphibians and reptiles of northeastern Kansas. Ibid. 8: 417-476.

- 1958. Natural history of the six-1ined racerunner (Cnemidophorus sexlineatus). Ibid. 11: 11-62.

Goin, 0. B. 1957. An observation of mating in the broad-headed skink, Eumeces laticeps. Herpetologica, 13: 155-156.

Grant, C. 1927. The blue-talled skink of Kansas (Eumeces guttulatus). Cope1a, no. 164: 67-69.

Jansen, H. S. 1954. Notes on the lizard Eumeces egregius in Georgia. Cope1a, 1954: 229.

Hamllton, H. J., Jr. and J. A. Pollack. 1956. The food of some colubrid snakes from Fort Benning, Georgla. Ecology, 37: 519-526.

- 1958. Notes on the 11 fe history of the red-talled skink. Herpetolog1ca, 14: 25-28. 
Kauffeld, C. F. 1941. The red-tailed skink, Eumeces egregius, in Alabama. Copeia, 1941: 51.

Laessle, A. M. 1942. The plant communities of the Welaka area. Univ. of Florida Biol. Sci. Ser. 4: 1-143.

- 1958. The origin and successional relationship of sandhill vegetation and sand-pine scrub. Ecol. Monogr. 28: 361-387.

LeBuff, C. R. 1960. The presence of certain herptiles in southwest Florida. Herpetologica, 16:197-198.

McConkey, E. H. 1957. The subspecies of Eumeces egregius, a lizard of the southeastern United States. Bull. Florida State Mus. 2: $13-23$.

Mecham, J. S. 1960. Range extensions for two southeastern skinks. Herpetologica, 16: 224.

Ne111, W. T. 1940. Bumeces egregius in Georgia. Copeia, 1940: 266.

Noble, G. K. and E. R. Mason. 1933. Experiments on the brooding habits of the lizards Eumeces and Ophisaurus. Amer. Mus. Nov. 619: $1-29$.

Rodgers, T. L. and V. H. Memnler. 1943. Growth in the western bluetailed skink. Trans. San Diego Soc. Nat. Hist. 10: 61-68.

Smith, H. M. 1946. Handbook of 1izards. Comstock Publishing Co., Ithaca, N. Y.

Tanner, W. W. 1957. A taxonomic and ecological study of the western skink (Eumeces skiltonlanus). Great Basin Nat. 17: 59-94.

Telford, S. R., Jr. 1959. A study of the sand skink, Neoseps reynoldsi Stejneger. Cope1a, 1959: 110-119.

Wharton, C. H. 1958. The ecology of the cottonmouths, Ancistrodon piscivorus piscivorus Lacepede, of Seahorse Key, Florida. Unpubl. Doctoral dissertation, Univ. of Florida. 


\section{BIOGRAPHICAL SRETCH}

Robert Hughes Mount was born on December 25, 1931, at Lewisburg, Tennessee. He graduated from Albany High School, Albany, Georgia, in June, 1950, and entered Alabama Polytechnic Institute (now Auburn University) the following September. He recelved the degree of Bachelor of Science in Fish Management from that institution in June, 1954, and that of Master of Science (Entomology) in June, 1956. He was employed by the Alabama Agricultural Experiment Station as an assistant in entomology from June, 1956, unt1l he entered the United States Army Medical Service Corps the following October. As a medical entomologist he served both in the United States and in the Far East. Immediately following his release from active duty in September, 1958, he entered the University of Florida and began his doctoral studies in b1ology.

Robert Hughes Mount is single and is a member of Alpha Gama Rho, Alpha Zeta, Gama Sigma Delta, Phi Kappa Phi, Sigma X1 (associate), the Ecological Society of America, the American Society of Ichthyologists and Herpetologists, and the Herpetologlsts' League. 
This dissertation was prepared under the direction of the chairman of the candidate's supervisory comittee and has been approved by al1 members of the committee. It was submitted to the Dean of the College of Arts and Sciences and to the Graduate Council and was approved as partial fulfillment of the requirements for the degree of Doctor of Philosophy.

August 12, 1961

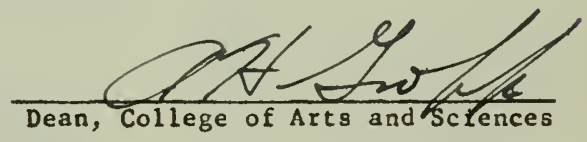

Dean, Graduate School

Supervisory Comittee:

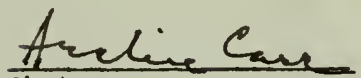

Chairman
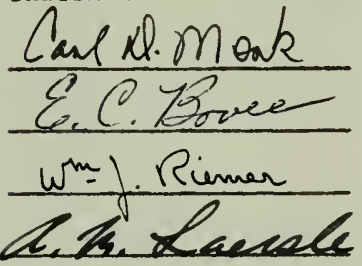


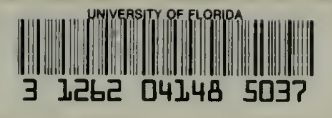

MARSTON SCIENCE LIBRARY
LD

1700

1961

. M128

3 
